\title{
Toward a Constitutional Review of the Poison Pill
}

\section{Citation}

Lucian A. Bebchuk \& Robert J. Jackson, Jr., Toward a Constitutional Review of the Poison Pill (Harvard John M. Olin Discussion Paper Series Discussion Paper No. 772, June 2014, 114 Colum. L. Rev. 1549 (2014)).

\section{Published Version}

http://www.law.harvard.edu/programs/olin_center/papers/pdf/Bebchuk_772.pdf;http:// columbialawreview.org/wp-content/uploads/2014/10/Bebchuk-Jackson.pdf

\section{Permanent link}

http://nrs.harvard.edu/urn-3:HUL.InstRepos:20269834

\section{Terms of Use}

This article was downloaded from Harvard University's DASH repository, and is made available under the terms and conditions applicable to Other Posted Material, as set forth at http:// nrs.harvard.edu/urn-3:HUL.InstRepos:dash.current.terms-of-use\#LAA

\section{Share Your Story}

The Harvard community has made this article openly available.

Please share how this access benefits you. Submit a story.

\section{Accessibility}


ISSN 1936-5349 (print)

ISSN 1936-5357 (online)

\section{HARVARD}

JOHN M. OLIN CENTER FOR LAW, ECONOMICS, AND BUSINESS

TOWARD A CONSTITUTIONAL REVIEW OF THE POISON PILL

Lucian A. Bebchuk

Robert J. Jackson, Jr

Discussion Paper No. 772

$06 / 2014$

Forthcoming, Columbia Law Review, Volume 114, October 2014

Harvard Law School

Cambridge, MA 02138

This paper can be downloaded without charge from:

The Harvard John M. Olin Discussion Paper Series:

http://www.law.harvard.edu/programs/olin_center/

The Social Science Research Network Electronic Paper Collection:

$\underline{\text { http://ssrn.com/abstract=2401098 }}$

This paper is also a discussion paper of the Harvard Law School Program on Corporate Governance 


\title{
Toward A Constitutional ReVIEW OF THE Poison PILL
}

\author{
Lucian A. Bebchuk* and Robert J. Jackson, Jr.** \\ Forthcoming, Columbia Law Review, Volume 114, October 2014
}

* William J. Friedman and Alicia Townsend Friedman Professor of Law, Economics, and Finance and Director of the Program on Corporate Governance, Harvard Law School.

** Associate Professor of Law and Milton Handler Fellow, Columbia Law School. Our work on this Article benefited from helpful suggestions of, and conversations with, Ronald Barusch, Steven Davidoff, Harold Edgar, Jeffrey Gordon, Richard Hall, Anton Metlitsky, Gillian Metzger, Henry Monaghan, Hashim Mooppan, David Pozen, Alex Raskolnikov, Richard Squire, Leo Strine, and Guhan Subramanian. We would also like to thank Jocelyn Hanamirian, Michael Herman, Benjamin Howard, Jennifer Thielen and Gabriella Wertman for exceptional research assistance. Finally, we are grateful to the Columbia Law School and the Harvard Law School, as well as to the Milton and Miriam Handler Foundation, for financial support. 


\begin{abstract}
$\underline{\text { Abstract }}$
We argue that the state-law rules governing poison pills are vulnerable to challenges based on preemption by the Williams Act. Such challenges, we show, could well have a major impact on the corporate-law landscape.

The Williams Act established a federal regime regulating unsolicited tender offers, but states subsequently developed a body of state antitakeover laws that impose additional impediments to such offers. In a series of well-known cases during the 1970s and 1980s, the federal courts, including the Supreme Court, held some of these state antitakeover laws preempted by the Williams Act. To date, however, federal courts and commentators have paid little attention to the possibility that the state-law rules authorizing the use of poison pills - the most powerful impediment to outside buyers of shares-are also preempted.
\end{abstract}

Our study examines this subject and concludes that there is a substantial basis for questioning the continued validity of current state-law rules authorizing the use of poison pills. We show that these rules impose tighter restrictions on unsolicited offers than state antitakeover regulations that federal courts invalidated on the grounds of preemption. Preemption challenges to these poison-pill rules could well result in their invalidation by the federal courts.

Finally, we discuss how state lawmakers could revise poison-pill rules to make them more likely to survive a federal preemption challenge. This could be done, we show, by imposing substantial limits on the length of time during which a poison pill can be used to block tender offers. Whether preemption challenges lead to invalidation of existing poison-pill state rules or to their substantial modification, such challenges could well reshape the market for corporate control.

Keywords: Corporate governance, Mergers and acquisitions, takeovers, tender offers, antitakeover defenses, poison pill, Williams Act, preemption, state antitakeover statutes.

JEL Classification: D21, G32, G34, G35, G38, K22 


\section{TABLE OF CONTENTS}

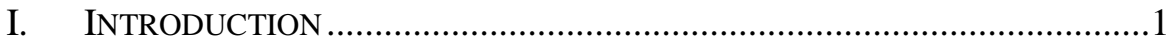

II. Constitutional ReVIEW Of StATE ANTITAKEOVER LAW .................8

A. The Williams Act and the States.........................................................

B. Federal Scrutiny of State Antitakeover Law .......................................10

1. First-generation takeover laws and Edgar v. MITE .......................10

2. Second-generation takeover laws and CTS v. Dynamics

Corporation of America ..................................................................12

3. Third-generation takeover laws and post-CTS cases.......................14

C. The Unresolved Validity of State-Law Poison-Pill Rules ....................18

III. The TRANSFORMATIVE EFFECT OF THE POISON PILL..........................22

A. The Tender-Offer Landscape at the Time of the Williams Act............22

B. State-Law Licenses to Use Pills .........................................................24

C. The Effect of the Poison Pill on the Tender-Offer Landscape .............26

D. State-Law Poison-Pill Rules Versus Traditional Antitakeover

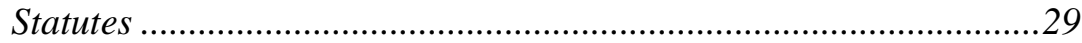

IV. Are State-Law Poison-Pill Rules Valid?.....................................33

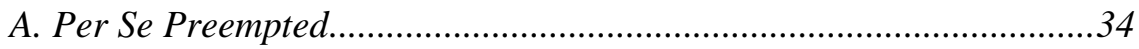

1. Meaningful opportunity for success ............................................35

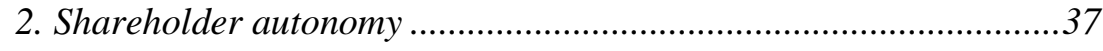

B. Preemption Depends on Overall Effect on Shareholder Value ..........39

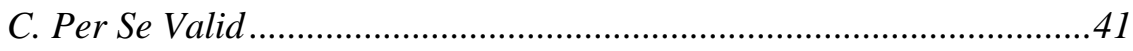

V. Changing State LAW TO Avoid PREEMPTION .................................47

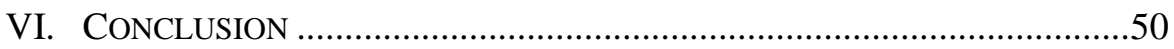




\section{Toward a Constitutional Review of the Poison Pill}

\section{INTRODUCTION}

Nearly all standard corporate-law casebooks include an account of the significant line of cases in which the federal courts reviewed the constitutionality ${ }^{1}$ of state antitakeover statutes. These textbooks, however, go on to express the accepted view among researchers and practitioners that these cases are no longer relevant to contemporary corporate law, because a private-law innovation - the poison pill-now dominates the antitakeover influence of state statutes. ${ }^{2}$ In this Article, we argue that this widely shared view is mistaken. ${ }^{3}$

We show that the cases in which the federal courts have evaluated the constitutionality of state antitakeover statutes raise serious questions about the validity of the state-law rules authorizing the use of the poison pill. The Article presents a systematic analysis of the possibility that these

\footnotetext{
${ }^{1}$ As we explain below, as a formal matter these courts considered whether the Williams Act preempts state antitakeover statutes-and, thus, whether such statutes are rendered void by operation of the Supremacy Clause. U.S. CONST. art. VI, cl. 2 (the "Constitution and the Laws of the United States . . . shall be the Supreme Law of the Land"); see also CTS Corp. v. Dynamics Corp. of Am., 481 U.S. 69 (1987) (applying the Supremacy Clause to state-law rules governing hostile takeovers); Edgar v. MITE Corp., 457 U.S. 624 (1982) (opinion of White, J.) (same). For ease of exposition, in this Article we occasionally refer to the invalidation of state law by operation of the Supremacy Clause as rendering such laws "unconstitutional."

${ }^{2}$ See, e.g., William T. AlLEN, Reinier KraAkMAN \& GUHAN SUbramanian, COMMENTARIES AND CASES ON THE LAW OF BUSINESS ORGANIZATION 588-97 (3d ed. 2009) (noting, in the course of describing the emergence of state antitakeover statutes and the cases addressing their constitutional validity, that "poison pills were [instead] the decisive legal development of the hostile takeover era”).

${ }^{3}$ This Article continues our recent work considering the interplay of federal constitutional law and state corporate law rules. See Lucian A. Bebchuk \& Robert J. Jackson, Jr., Corporate Political Speech: Who Decides?, 124 HARV. L. REV. 83 (2010); Lucian A. Bebchuk \& Robert J. Jackson, Jr., Shining Light on Corporate Political Spending, 101 GEO. L.J. 923 (2013).
} 


\section{Toward a Constitutional Review of the Poison Pill}

rules are preempted by the Williams Act and provides a framework for assessing preemption challenge to those rules. Litigation over the validity of these rules, we show, can have profound implications for the governance of American corporations.

The literature on the constitutionality of state antitakeover laws is quite substantial. Indeed, more than one hundred law review articles have considered whether and how the Williams Act might preempt various state statutes that govern corporate takeovers. ${ }^{4}$ Just three years ago, the Business Lawyer dedicated a symposium issue to analysis of whether the Williams Act preempts Delaware's business combination statute. ${ }^{5}$ Yet this large literature has paid limited attention to the question of whether the state-law rules with the most powerful antitakeover effect-the rules authorizing use of the poison pill-are preempted.

In this Article, we systematically analyze this question and conclude that there is substantial doubt as to whether current state-law poison-pill rules are valid. As we explain, these rules provide incumbents with an even more powerful antitakeover defense-and impose an even lengthier delay on tender offerors - than state statutes that the federal courts held to be invalid. The validity of state-law poison-pill rules thus should not be taken for granted, and we therefore provide a framework for analyzing preemption challenges to these rules.

Using this framework, we examine three alternative approaches that the federal courts may follow when faced with preemption challenges to the validity of state-law rules governing poison pills. Our analysis shows that the courts are likely to conclude that existing state-law poisonpill rules are preempted. We also examine what changes in existing statelaw rules might make them more likely to survive constitutional scrutiny.

${ }^{4}$ See infra text accompanying note 42 . For examples from this literature, see infra note 42 and sources cited therein.

${ }^{5}$ Guhan Subramanian, Steven Herscovici \& Brian Barbetta, Symposium: Is Delaware's Antitakeover Statute Unconstitutional? Evidence from 1988-2008, 65 Bus. LAW. 685 (2010). The symposium included several responses to an important article by Subramanian, Herscovici and Barbetta. See infra note 36 and sources cited therein. 


\section{Toward a Constitutional Review of the Poison Pill}

We show that state corporate law that substantially limits the length of time during which a poison pill can be used to delay tender offers would be more likely to withstand a preemption challenge than current state-law rules in this area.

The remainder of the Article proceeds as follows. In Part II, we review the Williams Act and the emergence of state antitakeover laws in the wake of its passage. ${ }^{6}$ We also discuss the large body of cases in which the courts have considered whether the Act preempts state antitakeover statutes. We explain that, despite this long line of cases, the federal courts have paid limited attention to the possibility that poison-pill rules are preempted by the Williams Act.

Part III discusses the legal landscape that the drafters of the Williams Act faced when they passed the Act in 1968. We show that this landscape was fundamentally altered by the emergence of state-law poison-pill rules that empower incumbents to delay tender offers for lengthy periods of time. Indeed, we explain, those rules provide incumbents with an even more powerful antitakeover defense-and impose an even lengthier delay - than the state statute that the Supreme Court invalidated as preempted by the Williams Act. Thus, we argue, the constitutional validity of current state-law rules governing poison pills should not be taken for granted.

Some prior work on the validity of state antitakeover laws has noted that poison pills are private contractual arrangements, suggesting that pills are thereby distinguishable from the state antitakeover laws that

\footnotetext{
${ }^{6}$ As one of us has argued in a series of articles, the evolution of state antitakeover law has been influenced by incumbents' interest in having more extensive protections from unsolicited tender offers than the Williams Act provided. See, e.g., Lucian A. Bebchuk, Federalism and the Corporation: The Desirable Limits on State Competition in Corporate Law, 105 HARV. L. REV. 1442 (1992); Lucian A. Bebchuk \& Allen Ferrell, Federalism and Takeover Law: The Race to Protect Managers from Takeovers, 99 CoLUM. L. REV. 1168 (1999); Lucian A. Bebchuk \& Alma Cohen, Firms’ Decisions Where to Incorporate, 46 J. L. \& ECON. 383 (2003).
} 


\section{Toward a Constitutional Review of the Poison Pill}

have been held preempted by the Williams Act. ${ }^{7}$ In Part III, we explain why the claim that these differences preclude preemption challenges to state-law poison-pill rules is mistaken. This view, we argue, overlooks the critical role that state-law rules play in permitting poison pills to delay tender offers for lengthy periods of time- - a result in considerable tension with the Williams Act. Furthermore, we show, some of the state antitakeover laws that were invalidated by the federal courts blocked only unsolicited offers that incumbent directors chose to oppose-just as statelaw poison-pill rules do today. The courts considering preemption challenges to those laws have not suggested that the presence of a private choice by directors precludes a preemption challenge to the state laws making that private choice possible. To the contrary, we explain, these courts proceeded to consider whether the challenged state law was consistent with the Williams Act.

Part IV provides a comprehensive analysis of how courts can be expected to approach preemption challenges to state-law poison-pill rules. We identify the three approaches that federal courts have followed in the past in evaluating claims that the Williams Act preempts state antitakeover laws, and we analyze the expected consequences that would follow if each approach were applied to current state law governing the poison pill. The first judicial approach we consider focuses on whether tender offerors are given a meaningful opportunity to successfully acquire the target and whether shareholders are given an opportunity to evaluate the merits of tender offers. We show that, if this analysis is applied to current state-law poison-pill rules, the courts would likely conclude that such rules are per se preempted.

Next, we consider judicial approaches from prior cases on Williams Act preemption that have focused on whether, in fact, the state law at issue enhances investor protection. We show that, if this approach is followed in an examination of the validity of current state-law poison-pill rules, courts will be required to hold evidentiary hearings to determine whether statelaw rules that allow incumbents to use the poison pill to delay tender offers in fact enhance shareholder value. We explain that, given existing evidence

${ }^{7}$ See, e.g., Subramanian et al., supra note 5, at 692; Larry Ribstein, Preemption as Micromanagement, 65 Bus. LAW. 789, 792 (2010). 


\section{Toward a Constitutional Review of the Poison Pill}

that the agency-cost effects of managerial entrenchment might impose significant costs on investors, this approach might well also result in the invalidation of state-law poison-pill rules.

Third, we consider an approach drawn from prior cases in which the courts have indicated that the Williams Act preempts only those state laws that conflict directly with the procedures mandated by the Act. If a court facing a preemption challenge to the validity of state-law poison-pill rules were to follow this approach, it would likely hold that these rules are per se valid. While we discuss this possibility, we provide reasons to believe that this approach is unlikely to carry the day among courts considering preemption challenges to state-law poison-pill rules. ${ }^{8}$

${ }^{8}$ In response to the arguments advanced in this Article, six senior partners of the law firm of Wachtell, Lipton, Rosen \& Katz, including founding partner Martin Lipton, have issued a twelve-page, single-spaced Memorandum arguing that "there has never been any doubt, and [there] never will be," that state-law rules authorizing the poison pill are consistent with the Williams Act. Martin Lipton et al., A Response to Bebchuk and Jackson's Toward a Constitutional Review of the Poison Pill, HARV. L. SCH. FORUM ON CORP. GOV. \& FIN. REG., available at http://blogs.law.harvard.edu/corpgov/2014/03/13/a-response-to-bebchuk-andjacksons-toward-a-constitutional-review-of-the-poison-pill/ (March 13, 2014) [hereinafter Wachtell Response]. The Wachtell Response relies upon the cases noted above, which hold the view that the Williams Act preempts only state-law rules that conflict directly with the procedures proscribed by the Act, and asserts that these cases reflect the "true state of the law." Id. In a detailed reply to the Wachtell Response, we explain that this assertion is unwarranted. See Lucian A. Bebchuk \& Robert J. Jackson, Jr., Toward a Constitutional Review of the Poison Pill: A Reply to Wachtell Lipton, HARV. L. SCH. FORUM ON CORP. GOV. \& FIN. REG., available at http://blogs.law.harvard.edu/corpgov/2014/03/17/toward-aconstitutional-review-of-the-poison-pill-a-reply-to-wachtell-lipton (March 17, 2014) [hereinafter Forum Reply].

As we explain there, the Wachtell Response does not provide an accurate description of the state of the law in this area. The Wachtell Response gives little weight, and occasionally fails to acknowledge, the federal-court decisions noted above and described in further detail below, see infra Parts IV.A and IV.B., that take different approaches to the Williams Act's scope. In our reply to the 


\section{Toward a Constitutional Review of the Poison Pill}

Once state lawmakers recognize that current state-law poison-pill rules may be preempted, they may wish to take steps to avoid that result. Thus, in Part IV, we provide a framework for lawmakers considering changes to state law designed to avoid preemption. Because the federal courts have emphasized the length of the delay that state-law rules impose on unsolicited tender offers, we explain, the risk of preemption may be considerably reduced by substantially limiting the period of time during which incumbents may use a poison pill to block tender offers they disfavor. While such revisions might ensure the survival of some state-law poison-pill rules, they would bring about a considerable change in the current law and practice of mergers and acquisitions.

Before proceeding, we note that some might be skeptical of our claim that state-law poison-pill rules may well be preempted because litigation based on such a claim has not yet been pursued. But it is not uncommon for claims that were ultimately successful to be brought to the attention of the courts after a long period of time during which they were not raised — even when the stakes have been significant, and the potential litigants have had substantial resources. For example, for decades wellcounseled corporations defended claims under the Alien Tort Statute based on events occurring outside the United States without arguing that the statute did not confer jurisdiction over such claims. ${ }^{9}$ Yet the Supreme Court recently declared that the ATS does not provide jurisdiction over such claims - an argument that was not raised by either the corporations or the courts involved in these prior cases. ${ }^{10}$ Similarly, companies have been

Wachtell Response, and in this Article, we explain why these approaches could well lead courts to conclude that state-law poison-pill rules are preempted. See id. ${ }^{9}$ See, e.g., Sinaltrainal v. Coca-Cola Co., 256 F. Supp. 2d 1345, 1353-54 (S.D. Fla. 2003) (describing claims against Coca-Cola based solely on events in Colombia; although Coca-Cola succeeded in having the claims dismissed, the company did not argue that the statute did not confer jurisdiction over claims based on those events); Iwanowa v. Ford Motor Co., 67 F. Supp. 2d 242 (D.N.J. 1999) (same, with respect to claims against Ford based on events in Germany during World War II).

${ }^{10}$ Kiobel v. Royal Dutch Petroleum Co., 133 S. Ct. 1659, 1668 (2013); Alan O. Sykes, Corporate Liability for Extraterritorial Torts Under the Alien Tort Statute and Beyond: An Economic Analysis, 100 GEO. L. J. 2161, 2178 (2012) ("Most 


\section{Toward a Constitutional Review of the Poison Pill}

defending ATS suits for many years without arguing that the statute does not reach the conduct of private corporations. ${ }^{11}$ Yet the Second Circuit, home to many such suits, recently held that corporations cannot be held liable under the statute at all. ${ }^{12}$ Thus, the fact that a preemption challenge to state-law poison-pill rules has not yet been pursued should not lead one to presume that such a challenge would be unlikely to succeed. Indeed, as we explain below, the argument that state-law poison-pill rules are preempted has a substantial likelihood of being accepted by the courts. ${ }^{13}$

While the literature on the constitutionality of state antitakeover law is rather extensive, this work, like previous caselaw, has paid

ATS actions to date have involved conduct within foreign nations. . . . [M]ost lower courts [and litigants] have simply assumed that such conduct is covered by the statute.”).

11 See, e.g., Doe v. Unocal Corp., 963 F. Supp. 880, 883 (C.D. Cal. 1997) (allowing a suit to proceed against a corporation without expressly addressing whether corporations, as opposed to natural persons, could be held liable under the ATS). See generally Julian G. Ku, The Curious Case of Corporate Liability Under the Alien Tort Statute: A Flawed System of Judicial Lawmaking, 51 VA. J. INT'L L. 353, 353 (2011) ("For over two decades, U.S. courts have held that private corporations . . . can be subject to lawsuits under the [ATS]. This approach . . . was so widely accepted that courts barely acknowledged the issue when deciding on cases involving corporate defendants.”).

${ }^{12}$ Kiobel v. Royal Dutch Petroleum Co., 621 F.3d 111, 149 (2d Cir. 2010), aff'd on other grounds, Kiobel, 133 S. Ct. at 1668. But see Flomo v. Firestone Natural Rubber Co., 643 F.3d 1013 (7th Cir. 2011) (holding that corporations can be held liable under the ATS); Sarei v. Rio Tinto, PLC, 671 F.3d 736 (9th Cir. 2011) (same); Romero v. Drummond Corp., 552 F.3d 1303 (11th Cir. 2008) (same); Doe v. Exxon Mobil Corp., 654 F.3d 11 (D.C. Cir. 2011) (same).

${ }^{13}$ In a just-released paper, Professor Guhan Subramanian quotes this paragraph of this Article and expresses agreement with our argument that the validity of state-law poison-pill rules should not be inferred from the lack of these challenges over a long period of time. See Guhan Subramanian, Delaware's Choice: A Brief Reply to Commentators (Harvard Law School Working Paper, March 2014) (on file with authors) (referring to our example as "powerful" and agreeing with our observation that "an unconstitutional [state law] can survive for decades without constitutional challenges”). 


\section{Toward a Constitutional Review of the Poison Pill}

insufficient attention to whether the Williams Act also preempts state-law poison-pill rules. In this Article, we provide a framework for future consideration of the validity of state-law rules governing poison pills. In our view, constitutional litigation over the subject may well have a transformative effect on the modern law of mergers and acquisitions and the corporate-law landscape throughout the United States.

\section{Constitutional ReView of State Antitakeover LAW}

In this Part, we introduce the law governing constitutional review of state antitakeover rules. We explain why the federal courts found it necessary to scrutinize whether the laws adopted by the states to regulate takeovers were preempted by the Williams Act and discuss the evolution of state antitakeover laws and judicial scrutiny of those laws. We then highlight that the federal courts have thus far not conducted a systematic constitutional review of these state-law poison-pill rules—by far the most important antitakeover rules in contemporary corporate law.

In Section A, we describe the Williams Act and the concerns that motivated Congress to enact it. In Section B, we describe the federal courts' approach to reviewing the relationship between the Williams Act and state antitakeover statutes. In Section C, we explain that the courts' analysis to date has not directly addressed the constitutionality of state-law poison-pill rules - rules that play a key role in the modern corporate governance landscape.

\section{A. The Williams Act and the States}

Until 1968, cash tender offers in the United States were unregulated. Motivated by the specter of coercive tender offers, ${ }^{14}$ in that year Congress passed the Williams Act, mandating federal regulation that

\footnotetext{
${ }^{14}$ While before 1968 coercive cash tender offers had been relatively uncommon, they became "daily fare for the readers of the financial page" in the late 1960s. Note, Cash Tender Offers, 83 HARV. L. REV. 377, 377 (1969); see also EDWARD Ross Aranow \& HERBERT A. EINHORN, TENDER OfFICERS FOR CORPORATE CONTROL 2-10 (1973) (documenting the rise of the cash tender offer).
} 


\section{Toward a Constitutional Review of the Poison Pill}

would require tender offerors to give investors sufficient time and information to decide whether to tender their shares.

The Williams Act, and the rules that the SEC has promulgated under the Act's authority, extensively regulate the terms of tender offers. They mandate, for example, that tender offers remain open for at least twenty business days, and that tender offerors open their offers to all shareholders and pay all who tender the "best" price. ${ }^{15}$

The Williams Act went through extensive revisions prior to its enactment as Congress debated how to establish the appropriate balance among the players in a tender offer — outside investors, shareholders, and management. Senator Williams himself acknowledged that his initial proposal might disfavor outside investors, and he withdrew the bill after discussions with SEC staff highlighted that problem. ${ }^{16}$ The Senator then introduced a second bill, noting that he had "taken extreme care with this legislation to balance the scales equally to protect the legitimate interests of the corporation, management, and shareholders," and that "[e]very effort ha[d] been made to avoid tipping the balance . . . in favor of management or in favor of the offeror." ${ }^{, 7}$ When a ccongressional hearing revealed that even his second proposal raised concerns that the statute shifted this balance too far in favor of insiders, ${ }^{18}$ Senator Williams introduced a third proposal, which eventually became the Williams Act. ${ }^{19}$

${ }^{15}$ See id. § 78(n)(d)(4)-(7); see also 17 C.F.R. § 240.14d-1 (2012); id. § 240.14d-6.

${ }^{16} 111$ Cong. Rec. 28257 (1965) (Statement of Sen. Williams) (acknowledging that this initial proposal would "obviously work to the disadvantage of corporate takeover specialists”). For a detailed analysis of the legislative history of the Williams Act, see WiLMER CUTLER PiCKERING HALE AND DORR LLP, THE Williams ACT: A TRUly “MODERN” Assessment (Aug. 5, 2011), available at http://blogs.law.harvard.edu/corpgov/files/2011/10/The-Williams-Act-A-TrulyModern-Assessment.pdf.

${ }^{17} 113$ Cong. Rec. 854 (1967) (Statement of Sen. Williams).

${ }^{18}$ See Full Disclosure of Corporate Equity Ownership and in Corporate Takeover Bids: Hearing Before the Subcomm. on Securities of the S. Comm. on Banking and Currency, 90 Cong. 134 (1967) (testimony of Prof. Stanley Kaplan of the University of Chicago Law School).

${ }^{19}$ Pub. L. No. 90-439, 82 Stat. 454 (1968). 


\section{Toward a Constitutional Review of the Poison Pill}

The Senator explained that his revisions were designed to "provide the offeror and management equal opportunity to present their case" to shareholders in the event of a tender offer. ${ }^{20}$

In the decades since the Williams Act became law, many States have developed legal arrangements designed to supplement the rules established by the Act. These supplemental state-law rules generally limited the ability of outside investors to take control of public companies-and therefore provided incumbents with additional protection from such investors. These developments raised the question whether, and to what extent, such state-law rules disrupted the "careful balance" between outside investors and management that Congress struck in the Williams Act-and, thus, were preempted by the Act. As we explain in the next Section, that question has been the focus of several decisions by the federal courts, including the Supreme Court.

\section{B. Federal Scrutiny of State Antitakeover Law}

Following the passage of the Williams Act, the States have adopted a wide range of rules that supplement the Act's regulation of takeovers. Accordingly, over time the federal courts have developed a series of doctrinal tests to evaluate whether the Williams Act preempts these state-law rules. As we explain below, however, the courts have not yet resolved the validity of the most important state-law rules in the modern corporate governance landscape: those authorizing the use of the poison pill.

\section{First-generation takeover laws and Edgar v. MITE}

Immediately after Congress adopted the Williams Act, some thirtyseven states enacted what are now known as "first-generation" takeover statutes. ${ }^{21}$ These laws typically imposed additional burdens upon takeover bidders-for example, by requiring that a proposed tender offer be submitted to state officials for approval.

${ }^{20} 113$ Cong. Rec. 24664 (1967).

${ }^{21}$ See, e.g., Neil Fabricant, Hostile Tender Offers: Can the States Shut Them Down?, 22 J. CORP. L. 27 (1996). 


\section{Toward a Constitutional Review of the Poison Pill}

The Supreme Court first examined the possibility that the Williams Act preempted such statutes in Edgar v. MITE Corp. ${ }^{22}$ In MITE the Court considered a preemption challenge to the Illinois Business Takeover Act, which allowed the Illinois Secretary of State to hold a hearing about any hostile tender offer, and authorized the Secretary to pass on the fairness of the offer-and enjoin a substantively unfair offer. ${ }^{23}$ Justice White, writing for a plurality, concluded that the Illinois law was preempted by the Williams Act. ${ }^{24}$

Noting that the proper preemption inquiry was whether the state law "frustrate[d] the objectives of the Williams Act," Justice White concluded that the Illinois statute impermissibly interfered with Congress's objectives in two ways. First, the provisions of the statute authorizing the Secretary of State to call a hearing "frustrate[d] the congressional purpose by introducing extended delay into the tender offer process"; according to Justice White, "[i]n enacting the Williams Act, Congress itself recognized that delay can seriously impede a tender offer, and sought to avoid it."25

Second, Justice White noted that the Williams Act implemented Congress's policy to protect investors "while maintaining the balance between management and the bidder." To do so, Congress required the bidder to "furnish the investor and the target company with adequate information, but there was no [intention] to do more than give incumbent management an opportunity to express and explain its position.,26

${ }^{22} 457$ U.S. 624 (1982). The Court's opinion in MITE expanded upon its analysis of the purpose of the Williams Act in Piper v. Chris-Craft Indus., 430 U.S. 1, 2224 (1977), in which the Court considered whether an implied cause of action arises under the Williams Act's provisions addressing fraud in the tender-offer context.

${ }^{23}$ Id. at 634-640 (citing ILL. REV. STAT., ch. 121 (1979)).

${ }^{24}$ MITE, 475 U.S. at 640.

${ }^{25}$ Id. (quoting Great Western United Corp. v. Kidwell, 577 F.2d 1256, 1277 (5th Cir. 1978) (internal quotation marks omitted)) (citing S. Rep. No. 550, 90th Cong., 1st Sess. 3-4 (1967)).

${ }^{26}$ MITE, 457 U.S. at 634 (quoting Rondeau v. Mosinee Paper Corp., 422 U.S. 49, 58 (1975) (internal quotation marks omitted)). 


\section{Toward a Constitutional Review of the Poison Pill}

However, Justice White explained, “[o]nce that opportunity was extended, Congress anticipated that the investor, if he so chose, and the takeover bidder should be free to move forward within the time frame provided by Congress." "27 "[T]he Williams Act and its legislative history . . . indicate that Congress intended investors to be free to make their own decisions," Justice White wrote, and the Illinois statute thus took "an approach quite in conflict with that adopted by Congress." 28

\section{Second-generation takeover laws and CTS v. Dynamics Corporation of America}

Following the Supreme Court's decision in MITE, several States repealed their first-generation takeover laws, and within four years, twenty-one States had adopted so-called "second-generation" takeover statutes, which typically deterred acquisitions by requiring a shareholder vote to approve the purchase of shares by any investor crossing specified

${ }^{27}$ MITE, 457 U.S. at 634.

${ }^{28}$ Id. at 639-40 (quoting MITE Corp. v. Dixon, 633 F. 2d 486, 494 (7th Cir. 1980)). In the course of its critique of this Article, the Wachtell Response claims that, in MITE, Justice White "[m]isread . . . the Williams Act," and that the Justice's “stunning[]” analysis is "unsupportable.” Wachtell Response, supra note 8. This criticism of our discussion of Justice White's analysis is wholly unwarranted.

Our analysis does not assume that Justice White's approach-although expressed in a plurality opinion-represents the current state of the law. We do note, however, that in CTS - the Supreme Court's last word in this area-the Court applied Justice White's framework to assess the Williams Act's preemptive scope. See infra text accompanying notes 31-35. The Wachtell Response contends that the Court employed Justice White's approach merely "for the sake of argument," Wachtell Response, supra note 8, but Supreme Court opinions generally do not apply in their analysis, even for the sake of argument, an approach that is "insupportable." Id. Furthermore, as we explain below, the Justices in CTS could have adopted the narrow view of the Williams Act urged in the Wachtell Response. Indeed Justice Antonin Scalia described a similar view in a separate opinion in CTS, see 481 U.S. at 94, but no other Justice joined that opinion. See infra text accompanying note 96. 


\section{Toward a Constitutional Review of the Poison Pill}

ownership thresholds-and excluding shares owned by the acquiror for purposes of this vote. $^{29}$

The Supreme Court considered whether the Williams Act preempted such statutes in CTS v. Dynamics Corporation of America. The Court concluded that an Indiana statute that limited acquirors' voting rights unless disinterested shareholders approved the transaction at a meeting to be held within fifty days of the offer was not preempted for two reasons. ${ }^{30}$ First, the Court noted that, although the statute might impose some delay on tender offerors, a fifty-day delay was not so unreasonable as to warrant preemption. Unlike the statute in MITE, ${ }^{31}$ which held the "potential for infinite delay," the Court held that the potential fifty-day delay imposed by the Illinois law was reasonable. ${ }^{32}$ Second, the Court noted that, unlike the statute in MITE, which empowered state officials to decide whether a tender offer could go forward, the Indiana law "allow[ed] shareholders to evaluate the fairness of the offer collectively," a result that supplemented, rather than undermined, the investor protections Congress mandated in the Williams Act. ${ }^{33}$

${ }^{29}$ For an especially insightful discussion of the emergence of second-generation statutes, see STEPHEN A. BAINBRIDGE, MERGERS AND ACQUISITIONS 40 (2008).

${ }^{30} 481$ U.S. 69 (1987) (citing Ind. Code Ann. § 23-1-42-1 et seq. (Supp. 1986)).

${ }^{31}$ The CTS Court expressly chose not to overrule MITE, noting only that Justice White's opinion had not commanded a majority. CTS, 481 U.S. at 82 \& n.6.

${ }^{32} \mathrm{Id}$. at 82-83. The Court acknowledged more generally that, by regulating tender offers at all, the Illinois statute "makes them more expensive and thus deters them somewhat," but held the law consistent with the Williams Act because "this type of reasonable regulation does not alter the balance between management and offeror in any significant way.” Id. at 82 n.7. That was true in CTS because the "principal result of the [Illinois law] is to grant shareholders the power to deliberate collectively about the merits of tender offers. This result is fully in accord with the purposes of the Williams Act.” Id.

${ }^{33}$ Id. (emphasis in original). The Court also pointed out that, if the Williams Act were construed to preempt "any state statute that may limit or delay the free exercise of power after a successful tender offer," id. at 86, "the Williams Act would preempt a variety of state corporate laws," including those permitting staggered election of directors. Id. at 82 n.7. Lower courts interpreting CTS have 


\section{Toward a Constitutional Review of the Poison Pill}

\section{Third-generation takeover laws and post-CTS cases}

In the wake of CTS, several States established new state-law arrangements further regulating tender offers. One type of law, the "business-combination" statute, prohibits a corporation from engaging in a business combination within a set time period after a shareholder acquires a particular level of share ownership. ${ }^{34}$ Some States have also adopted statutes expressly authorizing directors to adopt antitakeover arrangements like the poison pill, and limiting state courts' ability to review such

suggested that one implication of this language is that state antitakeover laws that block tender offerors from taking control of a company for a lengthy period after acquiring a majority of its shares are not preempted because the CTS Court seemed to approve state laws permitting staggered board elections, which similarly block hostile acquirors from taking control of the board for long periods of time. See, e.g., RP Acquisition Corp. v. Staley Continental, Inc., 686 F. Supp. 476, 486 (D. Del. 1988) (because the Supreme Court "advised" in CTS "that a two year delay [caused by a staggered board] before an acquirer obtains 'untrammeled authority' endures Supremacy Clause-Williams Act scrutiny," Delaware's business-combination statute, which imposes a three-year delay before a tender offeror can take control of the board, must also survive constitutional review). It might be argued that CTS's implicit approval of staggered-board arrangements suggests that state-law poison-pill rules are also unlikely to be preempted. As we explain below, however, see infra note 74, because state-law poison-pill rules can be used to block tender offerors from acquiring shares of the company's stock-rather than blocking offerors who have already acquired the company's stock from acquiring control—state laws authorizing staggered board elections do not implicate the Williams Act as directly as poison-pill rules. Thus, this argument is unlikely to persuade the courts that state-law poison-pill rules are not preempted.

${ }^{34}$ See, e.g., 8 DEL. Code ANN. TiT. § 203 (2012). Other States have adopted "constituency" statutes, which allow, or in some cases require, boards of directors to consider the interests of constituencies other than shareholders in determining what to do in response to a hostile takeover offer. See, e.g., ОHIO GEN. CORP. L. § 1701.59 (1988). 


\section{Toward a Constitutional Review of the Poison Pill}

arrangements. ${ }^{35}$ And in Delaware- the State whose law governs more than half of the publicly traded companies in the United States-the state law governing defensive tactics like the poison pill has been developed through judicial decisions. ${ }^{36}$

The federal courts have considered whether third-generation takeover laws are preempted by the Williams Act in several recent cases challenging business-combination statutes. These cases suggest that the courts will take one of three approaches when evaluating whether the Williams Act preempts state takeover rules. All of these courts agree that, where there is a direct conflict between the Williams Act and a state's takeover law, the state law will be held invalid. The courts are divided, however, with respect to whether there are meaningful constraints on state takeover law beyond those that directly conflict with the Williams Act.

The Supreme Court last spoke on Williams Act preemption in 1987, when the Court decided CTS. Since then, at least ten federal courts, including both courts of appeals and district courts, have examined the preemption of third-generation takeover laws, including the Seventh Circuit, Fourth Circuit, and First Circuit, as well as district judges in Delaware, Maryland, Wisconsin, and Georgia. As we explain below, these courts have produced widely divergent views on this subject. The decisions, however, can be usefully divided into three different approaches to the preemptive scope of the Williams Act.

a. Preemption due to conflict with congressional purpose. One group of federal courts has held that the Williams Act preempts state laws that interfere with Congress's purpose in promulgating the Act. Some have emphasized that, to be consistent with that purpose, the statute must give tender offerors a "meaningful opportunity for success." ${ }^{37}$ Others have

${ }^{35}$ Michal Barzuza, The State of State Antitakeover Law, 95 VA. L. REV. 1973, 1995 (2009) (describing such statutes); see also, e.g., VA. CODE ANN. § 13.1727.1 (West 2007) (expressly limiting state-court review of poison pills).

${ }^{36}$ Moran v. Household Int'l, Inc., 500 A.2d 1346, 1348 (Del. 1985); Unocal Corp. v. Mesa Petroleum Co., 493 A.2d 946, 955 (Del. 1985).

${ }^{37}$ See, e.g., City Capital Assoc. v. Interco, 696 F. Supp. 1551 (D. Del 1988); RP Acquisition Corp. v. Staley Continental, Inc., 686 F. Supp. 476 (D. Del. 1988); 


\section{Toward a Constitutional Review of the Poison Pill}

contended that state laws that interfere with investors' freedom to determine whether to accept a tender offer are preempted. ${ }^{38}$ All of the

BNS v. Koppers, 683 F. Supp. 458 (D. Del. 1988); see also West-Point Pepperell, Inc. v. Farley, Inc., 711 F. Supp. 1096, 1106 (N.D. Ga. 1989). In a recent symposium in the Business Lawyer assessing whether Delaware's business-combination statute, see 8 DEL. CODE ANN. TIT. § 203 (2012), is preempted by the Williams Act, the principal Article and three of the five Commentaries each assumed that this approach continues to govern analysis of Williams Act preemption claims. See Subramanian et al., supra note 5, at 705; see also Greg A. Jarrell, A Trip Down Memory Lane: Reflections on Section 203 and Subramanian, Herscovici, and Barbetta, 65 Bus. LAw. 779, 780 (2010) (noting that, at the time the Delaware legislature was considering Section 203, lawmakers were attempting to "avoid [having the statutes be] ruled unconstitutional," and the "trick was to make sure that the law somehow afforded a hostile bidder some meaningful chance to succeed”); Eileen Nugent, A Timely Look at DGCL Section 203, 65 BUS. LAW. 753, 756-57 \& n.22 (2010) ("the definition of 'meaningful opportunity for success' is itself key to any [constitutional] analysis”); A. Gilchrist Sparks, III \& Helen Bowers, After Twenty-Two Years, Section 203 of the Delaware General Corporation Law Continues to Give Hostile Bidders a Meaningful Opportunity for Success, 65 Bus. LAw. 761, 762 (2010) (describing this test as the "relevant legal standard"). But see Stephen P. Lamb \& Jeffrey M. Goris, A Practical Response to a Hypothetical Analysis of Section 203's Constitutionality, 65 Bus. LAW. 771, 774 (2010) (noting that later cases have cast "doubt" on whether the "meaningful opportunity for success" test is the appropriate analysis for Williams Act preemption); Ribstein, supra note 7, at 792 (2010) (arguing that the "meaningful opportunity for success” test provides little clear guidance to practitioners or lawmakers about how to avoid preemption of antitakeover statutes). $C f$. Guhan Subramanian, Steven Herscovici \& Brian Barbetta, Is Delaware's Antitakeover Statute Unconstitutional? Further Analysis and a Reply to Symposium Participants, 65 BUS. LAW. 799, 806 (2010) (arguing that the courts are likely to adopt the "meaningful opportunity for success" test in response to a Williams Act preemption challenge of Section 203, but that that choice is not "mandated by existing law").

${ }^{38}$ See, e.g., Hyde Park Partners, L.P. v. Connolly, 839 F.2d 837, 852 (1st Cir. 1988) (Coffin, J., for a unanimous panel including then-Judge Breyer) (state laws that let "management decide for investors instead of letting investors decide for 


\section{Toward a Constitutional Review of the Poison Pill}

decisions in this group, however, conclude that state laws in tension with Congress's broader purposes are preempted by the Williams Act.

We discuss these decisions, and their implications for the validity of state-law poison-pill rules, in Part III.A. below. As we explain there, courts taking this approach can be expected to conclude that current statelaw poison-pill rules are preempted by the Williams Act.

b. Preemption due to adverse effects on investor interests. Another set of decisions suggests that the Williams Act preempts only those state laws that are in fact detrimental for shareholders - that is, laws that can be shown to reduce shareholder value. ${ }^{39}$ On this view, the Williams Act sets a floor for the level of protection shareholders must receive in connection with tender offers; states are free to provide protection to investors above that level. State laws that reduce investor value, however, are preempted by the Act.

We discuss this approach and its likely effect on the validity of state-law poison-pill rules in Part III.B. below. As we explain there, courts taking this approach will have to determine whether state laws that empower directors to use the poison pill to delay tender offers for long periods of time enhance shareholder value.

c. Preemption only due to conflict with statutorily mandated procedures. Finally, some courts evaluating whether business-combination statutes are preempted by the Williams Act have concluded that the Act preempts only those laws that directly conflict with the procedures set

themselves" are likely to be preempted); RTE Corp. v. Mark IV Indust., Inc., 1988 WL 75453 (E.D. Wis. 1988) (state laws that "vest[] existing management with the power to block a tender offer . . . frustrate[] the purpose of the Williams Act”).

${ }^{39}$ Veere, Inc. v. Firestone Tire \& Rubber Co., 685 F. Supp. 1027, 1030 (N.D. Ohio 1988) (the Williams Act is not "a guarantee of a level playing field for offeror and management in the take-over game," but "a protection for investors while management and offeror are on the field"). 


\section{Toward a Constitutional Review of the Poison Pill}

forth in the Act. ${ }^{40}$ So long as the participants in a tender offer can comply with the requirements of both the Williams Act and state law, these courts have held, the state laws are not preempted. On this view, states may authorize antitakeover devices that completely block outside offers if states choose to do so.

We discuss these decisions and their likely implications for the validity of state-law poison-pill rules in Part III.C below. As we explain there, courts taking this approach are likely to hold that the Williams Act does not preempt these rules. But, as we also explain, courts considering a preemption challenge to state-law poison-pill rules are unlikely to adopt this approach.

\section{The Unresolved Validity of State-Law Poison-Pill Rules}

Commentators generally agree that the rules governing the poison pill are among the most important issues in contemporary corporate law. ${ }^{41}$ And, as we explain in the next Part, these rules are clearly the most important aspect of modern mergers and acquisitions. Despite these rules' importance, however, the courts have not clearly resolved whether the Williams Act preempts them. And, surprisingly, the unresolved constitutional status of these rules has received little attention from commentators.

Most importantly, although a significant number of judicial opinions have considered the constitutionality of various types of state antitakeover impediments, the federal courts have paid limited attention to the possibility that the Williams Act preempts state-law poison-pill rules.

${ }^{40}$ See Amanda Acquisition Corp. v. Universal Foods Corp., 877 F.2d 496, 498 (7th Cir. 1988); see also WLR Foods v. Tyson Foods, 65 F.3d 1172, 1172 (4th Cir. 1995); Realty Acquisition Corp. v. Property Trust of Am., 1989 WL 214477, at *5 (D. Md. 1989) (citing Amanda Acquisition, 877 F.2d at 496).

${ }^{41}$ See, e.g., ALLEN, KRAAKMAN \& SUBRAMANIAN, supra note 2, at 593 (3d ed. 2009) (noting that the poison pill "dominates" state takeover statutes because the pill makes it practically impossible to acquire a stake sufficient to trigger such statutes). 


\section{Toward a Constitutional Review of the Poison Pill}

To begin, neither of the Supreme Court cases in this area, Edgar and CTS, expressly considered this possibility with respect to poison-pill rules.

Moreover, the subsequent federal court decisions that expressed a willingness to impose limits on the scope of state antitakeover law did not expressly apply their analysis to state-law poison-pill rules. ${ }^{42}$ In one case, a federal trial court briefly indicated in dicta that such rules "may be preempted by the Williams Act." 43 But aside from this exception, the courts that have held that the Williams Act imposes meaningful limits on the devices that states can authorize to interfere with tender offers have not addressed whether the Act preempts state-law poison-pill rules.

The federal courts that have taken the view that the Williams Act imposes no substantive limits on the scope of state-law antitakeover devices have also paid little attention to whether the Act preempts statelaw poison-pill rules. It is worth noting that some discussion of this subject appears in two of the federal-court opinions taking this view of the Williams Act's preemptive scope. While these opinions focused on other state-law antitakeover rules, they did observe that their approach would lead to the conclusion that state-law poison-pill rules are not constitutionally problematic. $^{44}$ As we explain below, we acknowledge

${ }^{42}$ See, e.g., Hyde Park, 839 F.2d at 837, 852 (holding preempted state-law rules that let "management decide for investors instead of letting investors decide for themselves," but not applying this analysis to state-law poison-pill rules); RTE Corp., 1988 WL 75453 (holding that state laws that "vest[] existing management with the power to block a tender offer" are preempted, but not applying this analysis to the poison pill).

${ }^{43}$ See Southdown, Inc. v. Moore McCormack Resources, Inc., 686 F. Supp. 595, 604-05 (S.D. Tex. 1988) ("In reviewing the authorities on the use of the exclusionary-rights pill, it has occurred to the court that its only justification of buying time may be preempted by the Williams Act.”).

${ }^{44}$ See Amanda Acquisition Corp. v. Universal Foods Corp., 877 F.2d 496 (7th Cir. 1989) (suggesting, without holding, that "state law [that] enforces poison pills" could not "be thought preempted by the Williams Act"); WLR Foods v. Tyson Foods, 65 F.3d 1172, 1181 (4th Cir. 1995) (upholding a Virginia statute authorizing corporations to issue rights pursuant to poison-pill arrangements). 


\section{Toward a Constitutional Review of the Poison Pill}

that, should the federal courts adopt this approach to the Williams Act's preemptive reach, state-law poison-pill rules would be held per se valid. ${ }^{45}$ However, as we explain in detail in Part IV.C. below, the narrow approach to the Williams Act's preemptive scope put forward in these cases is unlikely to prevail in future cases and, ultimately, in the Supreme Court. ${ }^{46}$ Importantly, there is a body of cases that takes a substantially more expansive view of the preemptive reach of the Act. These cases have not explicitly addressed the poison pill—except for the brief dictum described above-but, as we explain below, their reasoning implies that state-law poison-pills are in significant tension with the Williams Act.

Like the federal courts, scholars have paid limited attention to whether the Williams Act preempts state-law poison-pill rules, despite extensive literature on the constitutionality of state antitakeover law more generally. Indeed, since 1982, when the Supreme Court first considered the constitutionality of such laws, academics and practitioners have published more than a hundred articles analyzing the caselaw on the constitutionality of state antitakeover statutes. ${ }^{47}$ This scholarship,

We also note that the Delaware Supreme Court addressed the possibility that the Williams Act preempts state-law poison-pill rules in the well-known case of Moran v. Household Int'l, Inc., 500 A.2d 1346 (Del. 1985). In that case, the Delaware Supreme Court held that such rules are not preempted. See id. at 1353. The views of state courts, however, are not binding on any federal court with respect to questions of federal law.

${ }^{45}$ See infra Part IV.C.

${ }^{46}$ See infra text accompanying notes 95-107 (noting that this view is difficult to reconcile with the text of the Williams Act, the Supreme Court's recent cases on the Supremacy Clause, and the fact that the Court could have adopted, but declined to adopt, such a view in CTS).

${ }^{47}$ A search of Westlaw's database of law reviews, texts, and bar journals for articles with the phrase "preemption" and "antitakeover" in the same sentence published since 1982 identified 113 such articles. Prominent examples of such articles include Ribstein, supra note 7, at 792; William W. Bratton \& Joseph A. McCahery, The Equilibrium Content of Corporate Federalism, 41 WAKE FOREST L. REV. 619, 657-58 (2006); Jeffrey N. Gordon, “Just Say Never”? Poison Pills, Deadhand Pills, and Shareholder-Adopted Bylaws: An Essay for Warren Buffett, 19 CARdozo L. Rev. 511, 512-13 (1997); Roberta S. Karmel, Is It Time for a 


\section{Toward a Constitutional Review of the Poison Pill}

however, has focused largely on antitakeover statutes, paying limited attention to the validity of state-law poison-pill rules. ${ }^{48}$

Following this literature, nearly every corporate-law casebook includes a substantial section describing constitutional litigation over state antitakeover statutes-but indicates that such statutes are irrelevant in light of the overwhelming influence of the poison pill on the state-law landscape. One leading casebook, for example, describes the major cases in this area before concluding that they are not practically relevant because the poison pill "dominates" state antitakeover laws. ${ }^{49}$ To the contrary, we show in this Article that these cases have not been rendered unimportant by the poison pill. Instead, these cases are necessary to understand whether the state-law rules governing the pill itself are vulnerable to constitutional challenge.

As we show in the next Part, the state-law rules that authorize the poison pill have indeed transformed the tender-offer landscape. Then, in

Federal Corporation Law?, 57 BROOK. L. REV. 55, 77-78 (1991); David W. Leebron, Games Corporations Play: A Theory of Tender Offers, 61 N.Y.U. L. REV. 153, 219-221 (1986); Jonathan R. Macey, Administrative Agency Obsolescence and Interest Group Formation: A Case Study of the SEC at Sixty, 15 CARDozo L. REV. 909, 944-45 (1994); Arthur R. Pinto, The Constitution and the Market for Corporate Control: State Takeover Statutes After CTS Corp., 29 WM. \& MARY L. REV. 699, $703-77$ (1988); and E. Norman Veasey, Jesse A. Finkelstein \& Robert J. Shaughnessy, The Delaware Takeover Law: Some Issues, Strategies and Comparisons, 43 BUS. LAW. 865, 877-78 (1988).

Recent significant contributions to this literature include Subramanian et al., supra note 4, and responses to that article in a recent Business Lawyer symposium (see Jarrell, supra note 36; Lamb \& Goris, supra note 36; Nugent, supra note 36; Sparks \& Bowers, supra note 36; Ribstein, supra note 7), and Guhan Subramanian, Delaware's Choice (The 2013 Pileggi Lecture), available at http://papers.ssrn.com/sol3/papers.cfm?abstract_id=2355035.

48 Articles that discuss state-law poison-pill rules include Lyman Johnson \& David Millon, Does the Williams Act Preempt State Common Law in Hostile Takeovers?, 16 SEC. REG. L. J. 339, 341 (1989), Ribstein, supra note 7, and Subramanian, supra note 47.

${ }^{49}$ ALLEN, KRAAKMAN \& SUBRAMANIAN, supra note 2, at 597. 


\section{Toward a Constitutional Review of the Poison Pill}

Part III, we turn to a comprehensive investigation of the validity of statelaw poison-pill rules.

\section{The Transformative Effect of the Poison Pill}

In this Part, we show that state-law rules authorizing unlimited use of the poison pill have drastically transformed the landscape that Congress contemplated when passing the Williams Act. Current state laws authorize boards to use poison pills to block outside tender offers from reaching shareholders indefinitely—or, at least, for a very long period of time. Indeed, as we explain below, these laws impede outside tender offers to an even greater extent than the laws invalidated by the Supreme Court in MITE. Moreover, recent changes in state law-including the increased prominence of state statutes endorsing use of the poison pill and the elimination of careful review of the use of the pill in the Delaware courts - have increasingly brought state law into tension with the purposes and objectives of the Williams Act.

In Section A below, we explain the legal and economic tenderoffer landscape that the drafters of the Williams Act faced when the statute was enacted in 1968. In Section B, we explain how state law empowers directors to use the pill to block outside tender offers. Finally, Section C shows how these state-law developments have altered the landscape that lawmakers considered when they first designed the Williams Act.

\section{A. The Tender-Offer Landscape at the Time of the Williams Act}

When Congress passed the Williams Act, cash tender offers were virtually unregulated. Senator Williams drafted the statute in light of that prevailing law, which gave outside investors considerable freedom with respect to the acquisition of public-company stock. In particular, outside investors were virtually assured that, so long as they abided the Act's requirements with respect to the terms and conditions of a tender offer, their offer would eventually be considered by shareholders. 


\section{Toward a Constitutional Review of the Poison Pill}

To be sure, Senator Williams sought to eliminate the abusive, coercive tender offers that had become commonplace in the years before the passage of the Act. ${ }^{50}$ That is why the statute extensively regulates the terms of such offers. Provided, however, that outside investors followed these rules, the drafters of the Williams Act expected, in light of the law in place in 1968, that managers and outsiders would have an opportunity to "fairly present their case" to investors, who could then decide whether to tender their shares. ${ }^{51}$

The structure and provisions of the statute and related regulations show that the Williams Act is designed to facilitate the choice that lawmakers presumed shareholders would have in the event of a tender offer. These rules include elaborate provisions that require bidders to provide extensive information to investors and the incumbent board to provide a recommendation to shareholders as to whether to accept the tender offer. ${ }^{52}$ The rules contemplate that, whether or not the board favors the offer, shareholders will be free, informed by the bidder's disclosures and the board's recommendation, to decide whether to accept the offer. ${ }^{53}$ Clearly, the drafters of the Williams Act did not contemplate the possibility that shareholders could be prohibited from making that decision in any cases in which incumbents prefer that result. As we explain in the next section, however, currently state law empowers

${ }^{50}$ See supra text accompanying note and note 8 and sources cited therein.

${ }^{51}$ S. REP. NO. 90-550 (describing the legislative debate that preceded the passage of the Williams Act); see also MITE, 457 U.S. at 639 ("Congress intended for investors to be free to make their own decisions.").

52 See 17 C.F.R. $\S \S 240.14 d-6(d)(1)$ (requiring disclosure of the identity and financing of hostile tender offerors); $240.14 \mathrm{e}-2$ (giving incumbent directors facing a hostile tender offer ten days to provide a statement indicating whether they recommend that shareholders accept or reject the offer).

53 Indeed, the SEC rules that require the incumbent board to make a recommendation to shareholders with respect to tender offers, see id., themselves assume that incumbents will be permitted only to recommend whether shareholders should accept a tender offer-not decide whether shareholders will be prohibited from even considering such an offer, as current state law empowers incumbents to do. 


\section{Toward a Constitutional Review of the Poison Pill}

incumbents to block tender offers from reaching shareholders for a significant period of time.

\section{B. State-Law Licenses to Use Pills}

As we have noted, the drafters of the Williams Act did not expect that state law would give directors the power to block tender offers. Nearly two decades after the Act was passed, however, corporate lawyers introduced the poison pill—a security that incumbents can issue to make the buying of shares beyond a specified threshold prohibitively costly and thereby prevent a takeover opposed by the board. ${ }^{54}$ The laws of a majority of the states now give directors the power to use this mechanism. ${ }^{55}$

Indeed, many States' corporation statutes have been amended to expressly authorize directors to use the poison pill. Furthermore, these statutes often mandate that the directors' choice to use the pill may be reviewed by the courts only through the lenient business judgment standard that any choice by directors must satisfy. In our view, because the poison-pill rules established by the statutes of these States are especially straightforward and clear, parties considering a challenge on the basis of Williams Act preemption should focus first on these jurisdictions.

In Delaware, the State whose law governs more than half of all publicly traded companies in the United States, the use of poison pill is instead governed by caselaw. Initially, after the well-known case of Moran v. Household International was decided in 1985, several commentators

54 See Allen, KRAAKMAN \& SubramANIAN, supra note 2, at 522-24 (recounting the history of the invention of the poison pill). The poison pill, also known as a "rights plan," permits directors to issue rights that allow shareholders to purchase the company's stock at a discounted price if someone acquires more than a certain percentage of that stock. The person or entity whose stock acquisition triggers the exercise of the rights, however, is excluded from buying discounted stock-making the decision to cross the pill's threshold, and thereby trigger other investors' rights to buy company stock at a discount, economically disastrous for the acquiring person.

55 In a 2009 review of all fifty States' takeover laws, Michal Barzuza demonstrated that a majority of States have adopted statutes expressly authorizing the use of the poison pill. See Barzuza, supra note 34, at 1989. 


\section{Toward a Constitutional Review of the Poison Pill}

expressed the hope that the state's courts would develop substantial limits on the power of incumbents to use a pill to block a tender offer they disfavored. ${ }^{56}$ However, over time, Delaware's judges instead adopted, and have followed since the early 1990s, a deferential approach to incumbents' use of poison pills. Indeed, during the last twenty years, despite the nearuniversal use of the poison pill, there has not been a single case in which Delaware law was held to require directors to redeem a poison pill.

For instance, in an early example of the ability of Delaware corporations to use poison pills to block unsolicited offers for lengthy periods, Circon blocked an offer from U.S. Surgical for more than a full year. ${ }^{57}$ In a more recent example, Airgas blocked an offer from Air Products for more than a year. ${ }^{58}$ In that case, when the retention of the poison pill was litigated in the Delaware Chancery Court, Chancellor Chandler concluded that the preceding delay had already given Airgas directors ample time to educate the company's shareholders on the merits of the hostile offer and that, in his "personal view, Airgas's poison pill ha[d] served its legitimate purpose. ${ }^{, 59}$ Yet Chancellor Chandler held that, notwithstanding his view that the poison pill had served its legitimate purpose, Delaware state law compelled him to allow the Airgas directors to keep the pill in place and thus to deny shareholders an opportunity to decide whether to accept the offer.

This pattern is consistent with the law in all States with rules authorizing the use of poison pills. Over the past two decades, despite the many cases in which incumbents have used the pill to block tender offers

56500 A 2d. 1346, 1357 (Del. 1985). See, e.g., Ronald J. Gilson \& Reinier Kraakman, Delaware's Intermediate Standard for Defensive Tactics: Is there Substance to Proportionality Review?, 44 Bus. LAW. 247 (1989).

${ }^{57}$ See Lucian Arye Bebchuk, John C. Coates IV \& Guhan Subramanian, The Powerful Antitakeover Force of Staggered Boards: Theory, Evidence \& Policy, 54 STAN. L. REV. 887, 913 (2002) (describing Circon's use of the pill to block a hostile offer by U.S. Surgical for nearly two years).

${ }^{58}$ The circumstances of this fight are described in detail in Chancellor Chandler's opinion in Air Products and Chemicals Inc. v. Airgas, 16 A.3d 48, 94 (Del. Ch. 2011).

${ }^{59} \mathrm{Id}$. 


\section{Toward a Constitutional Review of the Poison Pill}

for an extended period of time, we are unaware of a single instance in which state-law poison-pill rules have been held to require directors to redeem a poison pill and allow an offer to be considered by shareholders.

\section{The Effect of the Poison Pill on the Tender-Offer Landscape}

We now turn to the effects of these state-law rules on the modern law of tender offers. The emergence of the poison pill significantly altered the legal landscape that the drafters of the Williams Act expected to govern tender offers in 1968. The lawmakers who drafted the Act expected that, so long as outside bidders complied with the rules set forth in the Act, hostile offerors would be free to present their offer to shareholders.

But because pills make it prohibitively expensive for outsiders to proceed with a tender offer without management's assent, so long as a pill is in place a hostile bidder simply cannot proceed. Under current state law, the pill effectively gives management the power to stop a hostile bidder from presenting a tender offer to shareholders.

Moreover, today state-law poison-pill rules present more powerful impediments to outside offers than those imposed by the state laws that have been the subject of Williams Act preemption challenges in the Supreme Court. The Illinois statute struck down in MITE, for example, enabled incumbents to block disfavored tender offers from reaching shareholders for six months. ${ }^{60}$ The Supreme Court held that, because "the Williams Act and its legislative history indicate that Congress intended for investors to be free to make their own decisions," state laws giving incumbents the power to delay tender offers for a period far longer than the timeframe specified in the Williams Act were preempted by the Act. ${ }^{61}$ By contrast, today state law gives incumbents the power to block tender

${ }^{60}$ Edgar v. MITE Corp., 457 U.S. 624, 637 (1982) (opinion of White, J.) (citing ILL. REV. STAT. ch. 121 1/2, 137.57 (D) (1979), which permitted incumbents to request a state administrative hearing on the fairness of a tender offer that incumbents opposed).

${ }^{61}$ MITE, 457 U.S. at 639 (citing H.R. Rep. No. 1711, 90th Cong., 2d Sess., 4 (1968)). 


\section{Toward a Constitutional Review of the Poison Pill}

offers by empowering directors to adopt and keep pills in place for extended periods of time.

It is also worth noting thatstate-law poison-pill rules present a far greater impediment to hostile tender offers than those imposed by the Indiana statute upheld in CTS. By requiring hostile offers to be approved by shareholders, the Indiana statute enabled incumbents to delay tender offers for up to fifty days. The statute was substantively equivalent, then, to a poison pill that shareholders could remove through a shareholder vote after a fifty-day period. In approving the statute, the Supreme Court was careful to note the limited delay that the statute imposed, noting that the Court could "not say that [that] delay . . . [was] unreasonable."62 By contrast, state law now empowers directors to use the poison pill to delay hostile offers for periods of time that are an order of magnitude longer than fifty days-indeed, even longer than the six-month delay imposed by the Indiana statute struck down in MITE.

It might be argued that, despite current state-law poison-pill rules, hostile tender offerors can proceed by first replacing a majority of incumbent directors with new directors committed to redeeming the pill. However, most state antitakeover laws, like the poison pill, impose impediments only on offers not approved by incumbents. ${ }^{63}$ Moreover, as a practical matter, at most public companies today replacing incumbent directors would take a substantial amount of time. ${ }^{64}$ That period would

${ }^{62}$ CTS Corp. v. Dynamics Corp. of Am., 481 U.S. 69, 85 (1987).

${ }^{63}$ See, e.g., 8 DEL. CODE ANN. TIT. § 203 (2012).

${ }^{64}$ In the absence of a charter provision permitting the removal of directors without cause, a hostile bidder would be required to wait until the corporation's next annual meeting before the incumbents could be unseated-a wait that can be as long as a full year. See id. §141(k). Some 31\% of S\&P 500 companies currently permit removal of directors only for cause. Takeover Defenses, SHARKREPELLENT.NET, http://sharkrepellent.net (search results for firms that only permit removal without cause in the S\&P 500 index). Moreover, at corporations with bylaw provisions requiring advance notice of director nominations, a bidder must nominate alternative directors several months before the annual meeting - and, once that deadline has passed, the bidder must wait until the year after the next annual meeting to unseat the incumbents. 


\section{Toward a Constitutional Review of the Poison Pill}

almost certainly exceed the fifty-day delay imposed by the statute approved in CTS - and would also likely be longer than the six-month delay imposed by the law struck down in MITE.

It might also be argued that, despite the existence of state-law poison-pill rules, incumbents often ultimately agree to unsolicited offersincluding ones that they initially disfavor. Pressure from the marketplace as well as from investors, the argument goes, often leads incumbents to agree to allow such offers to reach shareholders. ${ }^{65}$ On this view, state-law poison-pill rules are not so draconian as to fully block unsolicited tender offers. But this observation is in no way inconsistent with the central proposition we have advanced in this Article: that state-law poison-pill rules impede unsolicited tender offers, and tip the balance against bidders, to a greater degree than antitakeover statutes held preempted by the federal courts.

Consider, for example, a hypothetical state where tender offers are governed by the Illinois statute invalidated in MITE. The six-month delay imposed by the statute would not prevent markets and investors from imposing pressure on directors to allow a hostile offer to go forward ultimately, and corporate elections might well still enable many unsolicited offers to ultimately succeed if they are favored by shareholders. Yet the six-month delay imposed by the Illinois law was nevertheless considered sufficiently substantial as to lead to its invalidation by the Supreme Court. Thus, the possibility that markets and investors might pressure corporate directors not to use the power that state-law poison-pill rules give them does not foreclose a successful preemption challenge against those rules.

Approximately $70 \%$ of S\&P 500 companies require at least ninety days' notice of nominees to the board. Id. (search results in the S\&P 500 index for firms with bylaws requiring ninety days' or more notice for nominations).

${ }^{65}$ See, e.g., Paul H. Edelman \& Randall S. Thomas, Corporate Voting and the Takeover Debate, 58 VAND. L. REV. 453, 477 (2005) (describing this dynamic). 


\section{Toward a Constitutional Review of the Poison Pill}

\section{State-Law Poison-Pill Rules Versus Traditional Antitakeover Statutes}

Even though state-law rules on the poison pill provide a much more powerful impediment to tender offers than the statutes examined in CTS and MITE, it might be argued that preemption analysis does not apply to state-law poison-pill rules because, unlike state statutes, those rules address private agreements between companies and investors. As we explain in this section, however, this distinction is unlikely to convince courts that state-law poison-pill rules are immune from preemption challenges under the Williams Act.

To be sure, traditionally Williams Act preemption challenges have involved state statutes that expressly give boards of directors the power to reject disfavored tender offers. By contrast, it might be argued, the poison pill reflects an agreement among private actors that, like most such arrangements, is enforced through state-law rules that sanction the agreement - and, thus, is not an appropriate subject of a preemption challenge. ${ }^{66,67}$

${ }^{66}$ A related argument is that the poison pill is enforced by virtue of the commonlaw decisions of state courts rather than state statutes, and thus is not subject to preemption analysis. But see Johnson \& Millon, supra note 48, at 341 ("[T]here is no reason in law or policy that compels constitutional review of takeover statutes while sparing the more pervasive principles of the common law from that same scrutiny”). In their article, Professors Johnson and Millon provided a thoughtful analysis of whether the Williams Act might preempt the state courts' approaches to non-shareholder interests at the expense of shareholders, the role of the board of directors in takeover cases, and the analysis used to determine whether shareholders have achieved the best possible outcome in a particular takeover contest. See id. at 355-59.

As we explain below, we do not focus on whether the Williams Act preempts state-law judicial decisions as opposed to state statutes or private agreements adopted pursuant to state law. See infra text accompanying notes 6569. Instead, for purposes of our analysis what is important is that state law now plays a critical role in allowing incumbents to block tender offers for lengthy periods of time. That fact alone is enough to raise serious questions as to whether the Williams Act preempts state-law poison-pill rules. See id. 


\section{Toward a Constitutional Review of the Poison Pill}

This distinction, however, makes little difference with respect to the analysis that the courts apply to preemption claims. In both cases, state-law rules play a critical role in allowing incumbents to block tender offers for long periods of time. The role of state law in giving incumbents this power is obvious when the law at issue is a state statute. But state law plays an equally critical role in empowering incumbents to block tender offers in the case of the poison pill.

For one thing, in the absence of state law sanctioning and providing for the enforcement of the pill, the pill could not give incumbents effective power to block tender offers they disfavor. Indeed, in some states the legislature affirmatively adopted statutes endorsing the poison pill before companies adopted these arrangements. ${ }^{68}$ But whether private actors or the state moved first to adopt poison pills is not important for our purposes. What is important is that state law is what enables incumbents to use the poison pill to block tender offers for long periods of time. To see this, note that, in jurisdictions around the world where corporate-law rules do not authorize the pill to be used in this way, incumbents cannot simply use private-law arrangements to block offers they disfavor. ${ }^{69}$ This illustrates that the pill is not merely a private-law innovation; instead, state-law rules are critical to the extent to which the pill empowers incumbents to block tender offers.

Nevertheless, it might be argued that the pill remains a private contract between the company and its shareholders, and preemption analysis typically does not apply to such arrangements. But this argument is also unlikely to persuade courts that the Williams Act does not preempt state-law poison-pill rules. To see why, consider an analogous example with respect to the preemptive scope of Section 16(b) of the Securities

${ }^{67}$ The Delaware Supreme Court took a similar view in concluding that state-law poison-pill rules were not preempted by the Williams Act in Moran v. Household Int'l, 500 A.2d 1346, 1353 (Del. 1985) (holding that preemption analysis is "not applicable to the actions of private parties").

${ }^{68}$ See, e.g., Barzuza, supra note 34, at 1994 (describing states in which pillendorsement statutes preceded widespread adoption of the pill).

69 See, e.g., Ronald J. Gilson, The Poison Pill in Japan: The Missing Infrastructure, 2004 COLUM. BUS. L. REV. 21, 40 (2004). 


\section{Toward a Constitutional Review of the Poison Pill}

Exchange Act of 1934, which requires executives to repay to the firm any "short-swing" profits that arise from their trading in the company's stock. ${ }^{70}$ Suppose that state law permitted companies to adopt private contracts with their executives that guaranteed insiders that any shortswing profits they paid to the company would be immediately reimbursed by the firm. Such arrangements would, of course, render Section 16(b) practically meaningless. We do not believe, of course, that existing state law permits these arrangements. But if it did, we have little doubt that such state laws would be preempted. And the fact that state law produced this result by sanctioning a private-law arrangement would in no way preclude a successful preemption challenge.

We are aware, of course, that Section 16(b) has been the subject of considerable scholarly criticism. ${ }^{71}$ Perhaps Congress should revise the statute - or even repeal it. ${ }^{72}$ But the Constitution does not permit the states to take matters into their own hands and undermine the effects of a federal law - even an objectionable law - if Congress fails to address its error.

Similarly, federal law prohibits corporate insiders from trading on inside information, denying executives potential profits from such trades. ${ }^{73}$ Suppose that, as a "private-law innovation," boards of directors agreed that executives could inform the company of hypothetical trades they would have made in the absence of a prohibition on insider trading, and at the close of each year, the company would pay the executives an amount equal to their hypothetical trading profits. ${ }^{74}$ Of course, state-law rules do

${ }^{70}$ Securities Exchange Act of 1934, Pub. L. No. 73-291, § 16(b), 48 Stat. 881 (codified as amended at 15 U.S.C. § 78(p) (2013)).

${ }^{71}$ For a collection of the scholarly and practitioner criticism of Section 16(b), see Steve Thel, The Genius of Section 16: Regulating the Management of Publicly Held Companies, 42 HASTINGs L.J.391, 392 \& nn.7, 8 (1991).

72 See, e.g., Maureen O'Connor, Toward a More Efficient Deterrence of Insider Trading: The Repeal of Section 16(b), 58 FORDHAM L. REV. 309, 310 (1989).

${ }^{73}$ See Securities Exchange Act of 1934, 15 U.S.C. $\S 78$ (2013); 17 C.F.R. $\S 240.10 \mathrm{~b}-5$ (2013).

${ }^{74}$ An innovation like this one might be motivated by the view that such an arrangement might well be optimal from shareholders' point of view. See HENRY MANNE, INSIDER TRADING AND THE STOCK MARKET 9-10 (1966). 


\section{Toward a Constitutional Review of the Poison Pill}

not currently permit boards of directors to contract with executives in this way. But suppose that state law was changed to authorize boards and executives to enter into arrangements, like this one, that thwart the federal prohibition on insider trading. There is little doubt that such state-law rules would be preempted by federal law.

It might also be argued that preemption analysis should not apply to state-law poison-pill rules because directors' actions pursuant to those rules are constrained by the fiduciary duties that directors owe to shareholders. For two reasons, however, the fact that directors' use of the pill is limited by their fiduciary duties does not preclude preemption of state-law poison-pill rules. First, the board's use of the traditional state statutes that have been the subject of preemption challenges is also limited by the directors' fiduciary duties. Since most of these statutes do not apply if directors approve the tender offer, the statutes are typically triggered only when the board decides not to approve the offer. ${ }^{75}$ Yet courts considering preemption challenges to these statutes have not said that the fact that the board's decision is subject to the directors' fiduciary obligations precludes a finding of preemption. ${ }^{76}$ Instead, these courts proceed to determine whether other features of the challenged state lawfor example, the extent of the delay that the law imposes on tender offers-are consistent with the purpose of the Williams Act.

Second, recall the examples we provided above to explain why corporations cannot enter into private arrangements that would evade the purposes of Section 16(b) of the Exchange Act or the federal law prohibiting insider trading. As we have explained, the board might very well conclude, in good faith, that because those federal rules have deleterious consequences for shareholders, the directors' fiduciary duties require that the board adopt such arrangements. Nevertheless, the fact that

${ }^{75}$ For example, in Delaware, the board can choose to waive the protections of that State's business-combination statute by approving the proposed transaction. See 8 DEL. CodE ANN. TIT. § 203 (2012).

${ }^{76}$ See Ribstein, supra note 7, at 794 (arguing that the fact that the use of the poison pill is "constrained by the board's fiduciary duty to the corporation" provides only a "shaky" distinction between the pill and other state-law antitakeover devices that have been subject to preemption analysis). 


\section{Toward a Constitutional Review of the Poison Pill}

the directors' fiduciary duties compel that action does not suggest that state law permits directors to take steps that would undermine the purposes of federal law. To the contrary, it is clear that such arrangements, and the state law that sanctioned them, would be preempted.

Given that the state-law rules on the poison pill have transformed the tender-offer landscape imagined by the drafters of the Williams Act, have provided incumbents with stronger antitakeover protections than those imposed by the statutes considered by the Supreme Court in MITE and CTS, and are not meaningfully different from the laws considered in those cases, an examination of the constitutional validity of these rules is necessary. Courts, commentators, and practitioners should not take for granted that state-law poison-pill rules would survive a preemption challenge. Instead, these rules should be analyzed in light of the standards the courts have provided for assessing claims that the Williams Act preempts state law. We provide such an analysis in the next Part.

\section{Are State-Law Poison-Pill Rules Valid?}

Although the courts have not yet addressed the constitutionality of state-law rules on the poison pill, previous cases provide three competing approaches that the courts have used to determine the preemptive scope of the Williams Act. In this Part, we describe those approaches and assess how courts applying each would likely rule on claims that the Williams Act preempts state-law rules governing the pill. All courts agree that there are circumstances under which state takeover statutes are preempted because they conflict with the Williams Act. The courts have diverged, however, with respect to the scope of the conflict that is necessary to convince the court that the state law must fall. ${ }^{77}$

\footnotetext{
${ }^{77}$ The standard that courts will use to assess preemption challenges to state-law poison-pill rules will depend, in part, on whether such challenges are framed as facial or as-applied. See United States v. Salerno, 481 U.S. 739 (1987); Wash. State Grange v. Wash. State Republican Party, 552 U.S. 442, 449 (2008) (quoting Washington v. Glucksberg, 521 U.S. 702, 739-40 \& n.7 (1997) (Stevens, J., concurring in judgment)). For present purposes, we put to one side the
} 


\section{Toward a Constitutional Review of the Poison Pill}

In Section A below, we consider two approaches found in the cases that would likely lead courts to conclude that current state-law rules on the poison pill are preempted by the Williams Act. In Section B, we explore an approach under which it is unclear whether state-law rules on the pill survive preemption. Finally, in Section C, we describe an approach that would lead the courts to conclude that state-law rules governing the pill are, as a matter of law, not preempted.

\section{A. Per Se Preempted}

Courts assessing preemption claims under the Williams Act have taken two different approaches that would likely lead to the conclusion that current state-law rules on the poison pill are per se invalid. In this Section, we discuss each of those frameworks - which emerged in parallel in the years following the Supreme Court's decision in CTS - in turn.

The first, known as the "meaningful opportunity for success" test, is derived from a series of federal court decisions evaluating the constitutionality of state business-combination laws, including City Capital Associates v. Interco. ${ }^{78}$ The second, the "shareholder autonomy" view, is reflected in several lower-court interpretations of the Supreme Court's analysis in MITE and CTS, including the First Circuit's opinion for a panel including then-Judge Breyer in Hyde Park Partners, L.P. v. Connolly. ${ }^{79}$

differences in the courts' approaches to facial and as-applied challenges. To the extent, however, that courts assess whether state-law poison-pill rules that permit incumbents to delay tender offers indefinitely can ever be applied consistently with the purposes of the Williams Act, such challenges would properly be considered facial challenges.

${ }^{78} 696$ F. Supp. 1551 (D. Del 1988). See also West-Point Pepperell, Inc. v. Farley, Inc., 711 F. Supp. 1096 (N.D. Ga. 1989); BNS v. Koppers, 683 F. Supp. 458 (D. Del. 1988); RP Acquisition Corp. v. Staley Continental, Inc., 686 F. Supp. 476 (D. Del. 1988). For a brief discussion of these cases, see supra text accompanying note 36 .

${ }^{79} 839$ F.2d 837, 852 (1st Cir. 1988). 


\section{Toward a Constitutional Review of the Poison Pill}

\section{Meaningful opportunity for success}

Four federal courts that have considered whether the Williams Act preempts state business-combination statutes have concluded that the "power of the states to regulate tender offers does not extend to complete eradication of hostile offers." ${ }^{, 00}$ Nevertheless, because the "states have a legitimate interest in regulating tender offers," these courts have held, the "question [is] to what extent a state may limit them" consistent with the Williams Act. ${ }^{81}$ To ascertain the scope of Williams Act preemption, then, these courts ask, among other things, whether the state law "imposes an indefinite or unreasonable delay on offers." ${ }^{82}$

On this approach, even a state law, such as Delaware's businesscombination statute, that "alters the balance between target management and the offeror, perhaps significantly," is constitutional, "so long as hostile offers enjoy a "meaningful opportunity for success." "83 Because state business-combination statutes typically contain exceptions that permit hostile offerors to obtain control in some circumstances, these courts have held those statutes not preempted ${ }^{84}$ under the meaningful-opportunity-for-

${ }^{80}$ BNS, 683 F. Supp. at 468.

${ }^{81}$ Id. at 469 .

${ }^{82} \mathrm{Id}$. at 470 .

${ }^{83}$ BNS, 683 F. Supp. at 470; West-Point Pepperell, Inc., 711 F. Supp. at 1102 (quoting BNS, 683 F. Supp. at 469).

${ }^{84}$ See, e.g., id. at 470 . All four courts that have adopted this test have left open the possibility that future evidence might show that the requirements of these statutory exceptions are met so rarely that a hostile offeror's opportunity for success is not "meaningful," and thus that the Williams Act preempts the state law. See, e.g., id. at 471. As we have noted, in a 2010 article Guhan Subramanian, Steven Herscovici, and Brian Barbetta accepted the courts' invitation to evaluate this question empirically with respect to Delaware's business-combination statute. See Subramanian et al., supra note 5, at 685. The authors found that, over a period of nineteen years, no bidder had endured the statute's three-year waiting period and succeeded in acquiring its target, and argued that this finding cast the constitutionality of the Delaware statute into doubt under the meaningful opportunity for success test. See id. at 686. To our knowledge, however, the courts have not yet systematically revisited the 


\section{Toward a Constitutional Review of the Poison Pill}

success approach. ${ }^{85}$

However, we would expect courts applying this test to hold statelaw rules governing the poison pill to be preempted by the Williams Act. As explained in Part II, these rules give hostile offerors no practical opportunity for success, because they allow incumbents to block a hostile offer from shareholder consideration for long periods of time. In nearly all States-like in Delaware, as the recent decision in Airgas demonstratesstate law permits directors to use the pill to delay a tender offer for a sufficiently lengthy period that hostile bidders have no practical opportunity to acquire control. ${ }^{86}$

argument that Delaware's business-combination statute is preempted by the Williams Act. But however such claims are resolved, there can be little doubt that state-law rules on the poison pill leave no practical opportunity for success for a hostile tender offeror.

${ }^{85}$ In their response to this Article, several senior partners of Wachtell, Lipton contend that the decisions of these courts are "now discredited." Wachtell Reponse, supra note 8. We note, however, that these decisions have never been overruled by an authoritative court, and the assertion that they have been "discredited" is thus wholly unwarranted. These decisions, and the meaningful opportunity for success test for determining the scope of the Williams Act's preemptive reach, remain the law of the jurisdictions where these cases were decided.

${ }^{86}$ As we have noted, some courts adopting the "meaningful opportunity for success" test have pointed out that the CTS Court suggested that state-law rules that block majority shareholders from obtaining control, such as those permitting staggered board elections, are not preempted by the Act. See CTS, 481 U.S. at 82 n.7; see also supra note 28 (citing RP Acquisition Corp. v. Staley Continental, Inc., 686 F. Supp. 476, 486 (D. Del. 1988)). Importantly, however, these courts were evaluating the constitutionality of Delaware's business-combination statute, which, like state-law rules permitting staggered boards, block large shareholders from obtaining corporate control. By contrast, state-law poison-pill rules allow incumbents to block tender offerors from presenting their offers to purchase the company's stock to its shareholders — offers that are extensively regulated by the Williams Act. Thus, the possibility that the CTS Court endorsed state-law rules 


\section{Toward a Constitutional Review of the Poison Pill}

It might be argued that state-law poison-pill rules provide hostile tender offerors with some possibility of success because those rules authorize use of the pill only where directors can show that their decisions were the product of valid business judgment. We do not, however, expect that this argument will persuade courts using this approach that state-law poison-pill rules currently give hostile tender offerors a meaningful opportunity for success. It is commonly understood that the businessjudgment standard requires only that directors observe basic procedural obligations in connection with corporate decisions, and in fact the rule expressly prohibits courts from engaging in substantive review of directors' decisions. ${ }^{87}$ Thus, courts are unlikely to conclude that state law authorizing directors to permanently block tender offers on the basis of such a limited showing gives offerors the meaningful opportunity for success necessary to avoid Williams Act preemption.

\section{Shareholder autonomy}

Other lower federal courts have held that, because Congress's purpose in passing the Williams Act was to protect investors' freedom to decide whether to accept a tender offer, the Williams Act preempts state laws that compromise shareholders' autonomy in that context. These courts emphasize language in the Supreme Court's decisions in MITE and CTS that focus on the potential effects of state law on shareholders' freedom to receive, and to decide whether to accept, a tender offer. ${ }^{88}$

permitting the staggered election of directors does not suggest that state-law poison-pill rules are not preempted by the Williams Act.

${ }^{87}$ See, e.g., ALLEN, KRAAKMAN \& SUBRAMANIAN, supra note 2, at 250 (“[T] he business judgment rule means that courts will not decide whether the decisions of corporate boards are either substantively reasonable or sufficiently wellinformed").

${ }^{88}$ CTS Corp. v. Dynamics Corp. of Am., 481 U.S. 69, 84 (1987) (concluding that a state law was not preempted by the Williams Act because it "allows shareholders to evaluate the fairness of an offer collectively" (emphasis in original)); Edgar v. MITE Corp., 457 U.S. 624, 634 (1982) (holding a state takeover statute preempted because the drafters of the Williams Act envisioned 


\section{Toward a Constitutional Review of the Poison Pill}

For example, a First Circuit panel concluded in Hyde Park Partners, L.P. v. Connolly that a Massachusetts antitakeover statute was likely preempted because the law interfered with investors' freedom to determine whether to accept a tender offer. ${ }^{89}$ One of the members of the panel who issued this opinion was then-Judge Stephen G. Breyer, now a sitting Justice of the Supreme Court of the United States. The First Circuit took the view that the law "only serve[d] to decrease shareholders' ability to take advantage of tender offers" and thus could not be reconciled with Congress's purpose in adopting the Williams Act; a state law that "lets management decide for investors instead of letting investors decide for themselves," the court concluded, is preempted. ${ }^{90,91}$

We would also expect courts applying the shareholder-autonomy framework to hold state-law rules governing the poison pill preempted by the Williams Act. As we have explained, state-law rules today empower directors to adopt arrangements that permit incumbents, rather than investors, to decide whether shareholders may accept a tender offer. ${ }^{92}$ We

that "the investor, if he so chose, and the takeover bidder should be free to move forward [with the tender offer] within the time frame provided by Congress").

${ }^{89} 839$ F.2d 837, 852 (1st Cir. 1988).

${ }^{90}$ Id. at 852; see also RTE Corp. v. Mark IV Indus., Inc., 1988 WL 75453, at *3 (E.D. Wis. 1988) (holding a Wisconsin law preempted by the Williams Act because the Supreme Court had held in CTS that "the primary purpose of the Williams Act[ was] the promoting of investor choice," and the "Wisconsin act ... gives to the management of target companies a virtual veto power over the outcome of a tender offer contest” (citing CTS, 481 U.S. at 84)).

${ }^{91}$ Wachtell Lipton's response to this Article downplays the significance of the Hyde Park decision, and indeed does not identify the case by name or acknowledge that the opinion was joined by Justice Breyer. See Wachtell Response, supra note 8 (referring to the decision only in an electronic hyperlink). In our view, Hyde Park - especially given that it was joined by a judge who is now a sitting Justice of the Supreme Court-is a significant decision that is likely to be part of the mix of considerations that will influence future courts' assessments of the proper scope of the Williams Act.

92 See, e.g., Air Prods. and Chems. Inc. v. Airgas, Inc., 16 A.3d 48, 55 (Del. Ch. 2011) (“[A]s Delaware law currently stands . . . the power to defeat an inadequate hostile tender offer ultimately lies with the directors.”). 


\section{Toward a Constitutional Review of the Poison Pill}

acknowledge, of course, that supporters of these state-law rules contend that denying shareholders this choice ultimately benefits investors. Many, including one of us, have disputed that claim. ${ }^{93}$ For purposes of the shareholder-autonomy view, however, the merits of that debate are irrelevant. Instead, what is important is that courts applying a shareholderautonomy framework to the Williams Act have held that state laws that limit investors' freedom to accept tender offers are preempted. Because state-law poison-pill rules currently deprive shareholders of the freedom to accept hostile tender offers, we can expect courts adopting this approach to conclude that state-law rules governing the poison pill are preempted.

\section{B. Preemption Depends on Overall Effect on Shareholder Value}

Some courts examining the preemptive scope of the Williams Act have concluded that whether a particular state takeover law is preempted depends on whether, in fact, the law enhances shareholder protection. On this approach, which emphasizes the shift in the Supreme Court's analysis between MITE and CTS, ${ }^{94}$ courts hold that the Williams Act establishes a

93 Compare, e.g., Martin Lipton, Takeover Bids in the Target's Boardroom, 35 Bus. LAW. 101 (1979) with Ronald J. Gilson, The Case Against Defensive Tactics in Tender Offers, 33 StAn. L. Rev. 819 (1981) and Lucian Arye Bebchuk, The Case for Facilitating Competing Tender Offers, 95 HARV. L. REV. 1028 (1982).

${ }^{94}$ The MITE Court expressly emphasized shareholder autonomy rather than shareholder protection as a principal purpose of the Williams Act. MITE, 457 U.S. at 640 (concluding that a state may not "offer[] investor protection at the expense of investor autonomy" and therefore striking down a law that the state characterized as providing investors with critical protection against coercive tender offers). By contrast, the CTS Court held that states may protect investors by depriving them of choice in the tender-offer context so long as the "principal result" of the state law is to protect shareholders. CTS, 481 U.S. at 83. See also Piper v Chris-Craft Indus., 430 U.S. 1., 34 (1977) ("The legislative history . . . shows that the sole purpose of the Williams Act was the protection of investors who are confronted with a tender offer.”); Veere, Inc. v. Firestone Tire \& Rubber Co., 685 F. Supp. 1027, 1030 (N.D. Ohio 1988) (comparing the Court's opinions in MITE and CTS and concluding that the CTS majority viewed the Williams Act "not as a guarantee of a level playing field for offeror and management in the 


\section{Toward a Constitutional Review of the Poison Pill}

lower bound for shareholder protection in the tender-offer context. The states are free, on this view, to provide additional protection for investors. But for state-law regulation of tender offers to survive Williams Act preemption, the evidence must indicate that the statute generally protects investors - that is, that the law, on average, enhances shareholder value.

Courts applying this approach to claims that the Williams Act preempts state-law poison-pill rules will have to form a judgment on whether state laws that give directors the power to permanently block tender offers enhance shareholder value. Those defending these rules would have to engage substantively with the costs of allowing management to block tender offers, and particularly the possibility that permitting management to do so increases agency costs and managerial slack — and the accumulating evidence that these costs are significant. We note that, for example, in a study co-authored by one of us, takeover targets with staggered board elections - which are able to make the most use of state-law poison-pill rules to turn away hostile tender offersperformed much worse than companies without staggered boards. ${ }^{95}$ These companies were able to use the power conferred upon directors by state law to remain independent much more often than companies that were less able to take advantage of those rules. The study found that, on average, remaining independent reduced shareholder value at these firms. ${ }^{96}$

Of course, a complete analysis of the empirical evidence on the shareholder-value implications of empowering managers to block hostile offers is beyond the scope of this Article. We expect that this question will be hotly debated if the federal courts adopt a shareholder-value approach to Williams Act preemption in litigation over the constitutionality of statelaw poison-pill rules. In the course of such litigation, the parties will likely provide experts to opine on the effects of such state-law rules on shareholder value, and the courts will have to review those opinions as well as the extensive body of theoretical and empirical literature on this

take-over game," "but as a protection for investors while management and offeror are on the field").

${ }^{95}$ See Bebchuk et al., supra note 54, at 887-888.

${ }^{96}$ See id. at 902. 


\section{Toward a Constitutional Review of the Poison Pill}

question to determine whether, in the view of the court, state-law poisonpill rules do, in fact, protect shareholders. ${ }^{97}$

A comprehensive analysis of this question is beyond the scope of this Article. In previous work, one of us has presented a detailed review of the overall effect of these rules on shareholders. ${ }^{98}$ For purposes of this Article, we note only that, at a minimum, the arguments that the use of state-law poison-pill rules to block tender offers disfavored by incumbents for long periods of time in fact reduce shareholder value should be taken seriously. In particular, the courts will have to consider the agency costs that result from such rules, which insulate incumbent managers from the possibility of a hostile takeover and give rise to considerable managerial slack. In sum, if courts considering preemption challenges to state-law poison-pill rules emphasize shareholder value, there is a substantial likelihood that they will conclude that such rules are preempted.

\section{Per Se Valid}

The courts might also adopt an approach to Williams Act preemption that would lead them to conclude that state-law poison-pill rules are generally not preempted. On this view, the Williams Act preempts only those state laws that directly conflict with the procedures mandated by the Act. Thus, under this framework the Williams Act imposes virtually no limits on the power that state law may give directors with respect to tender offers. Although this approach would Ishield statelaw poison-pill rules from Williams Act preemption, as we explain below, relatively few courts have adopted it. ${ }^{99}$

${ }^{97}$ For seminal early works in this literature, see, e.g., Frank H. Easterbrook \& Daniel R. Fischel, The Proper Role of a Target's Management in Responding to Hostile Takeovers, 94 HARV. L. REV. 1161 (1981); see also Bebchuk, supra note 80, at 1031; Gilson, supra note 80, at 822; Lipton, supra note 80, at 103.

${ }^{98}$ See Lucian Arye Bebchuk, The Case Against Board Veto in Corporate Takeovers, 69 U. CHI. L. REV. 973, 995-1026 (2002).

99 As we have noted, Judge Frank Easterbrook described this approach in an opinion for a unanimous panel of the Seventh Circuit, see Amanda Acquisition Corp. v. Universal Foods Corp., 877 F.2d 496, 498 (7th Cir. 1988), and in that 


\section{Toward a Constitutional Review of the Poison Pill}

The judges who have adopted this framework have given three principal reasons for interpreting the Williams Act's preemptive scope narrowly. First, they note that, when Congress added the Williams Act to the Securities Exchange Act of 1934, the legislation did not remove a provision from the Exchange Act stating that nothing contained in the Exchange Act "shall affect the jurisdiction of the securities commission (or any agency or officer performing like functions) of any State over any security . . . insofar as it does not conflict with the provisions of this chapter," suggesting that Congress did not intend for the Williams Act to preempt state law. ${ }^{100}$ Second, they note that, in general, the courts presume that state law is not preempted by federal law, particularly in areas in which states have traditionally had significant authority. ${ }^{101}$ Finally, Judge Easterbrook has argued that the Williams Act merely "regulates the process of tender offers," including "timing[ and] disclosure"; thus, only a state law that "alters[s] the procedures governed by federal regulation" should be held preempted. ${ }^{102}$ A broader approach, Judge Easterbrook has

opinion Judge Easterbrook indicated that, on this view, state-law poison-pill rules “could [not] be thought preempted" by the Williams Act. Id. at 504. Similarly, as noted above the Fourth Circuit adopted a similar view in WLR Foods, Inc. v. Tyson Foods, Inc., 65 F.3d 1172, 1180 (4th Cir. 1995), and similarly rejected a broad challenge to a Virginia statute permitting the adoption of rights plans. Justice Antonin Scalia described a similar view in a separate opinion in CTS, see 481 U.S. at 94, but no other Justice joined that opinion.

10015 U.S.C. §§ 78bb(a) (2012); see also CTS, 481 U.S. at 96 (Scalia, J., concurring in the judgment) ("Unless it serves no function, that language forecloses preemption on the basis of conflicting 'purpose' as opposed to conflicting 'provision.'”); Amanda Acquisition Corp. v. Universal Foods Corp., 877 F.2d 496, 502 (7th Cir. 1989) (arguing that Williams Act "[p]reemption has not won easy acceptance among the Justices for several reasons,” including 15 U.S.C. §§ 78bb(a) (2012)).

${ }^{101}$ Amanda Acquisition, 877 F.2d at 502 ("Then there is the traditional reluctance of the federal courts to infer preemption of state law in areas traditionally regulated by the States. . . . States have regulated corporate affairs, including mergers and sales of assets, since before the beginning of the nation." (quoting California v. ARC America Corp., 490 U.S. 93, 109 (1989) (internal quotation marks omitted))).

${ }^{102}$ Amanda Acquisition, 877 F.3d at 503. 


\section{Toward a Constitutional Review of the Poison Pill}

explained, would improperly lead courts to question the constitutionality of basic state corporate-law rules governing matters such as shareholder voting. ${ }^{103}$

In the event that a preemption challenge to state-law poison-pill rules reaches the Supreme Court, we do not expect that these arguments will ultimately prevail. ${ }^{104}$ With respect to the claim that the Exchange Act's provision preserving the authority of state securities agencies reflects congressional intent to avoid preemption of state law, although Justice Scalia described this view in a separate opinion in CTS, no other Justice joined that opinion. To be sure, all eight of the Justices who declined to join Justice Scalia's opinion in CTS have since been replaced. Nevertheless, the fact that Justice Scalia's opinion drew no additional support at the time CTS was decided suggests that this view is unlikely to persuade a majority of today's Court. Furthermore, the language used in the provision differs markedly from the language Congress customarily uses to express its intent to avoid preemption of state law. ${ }^{105}$

${ }^{103}$ Id. (arguing that, on a broader view of Williams Act preemption, state laws governing shareholder voting could be preempted).

${ }^{104}$ For purposes of this Article we put to one side whether this approach to Williams Act preemption is normatively desirable, although other commentators have urged that this view be adopted. See, e.g., Stephen Bainbridge, The Constitutionality of the Delaware Takeover Statute, PROFESSORBAINBRIDGE.COM (November 10, 2009) (arguing that "courts today would follow Amanda Acquisition" rather than other approaches to Williams Act preemption); available at http://www.professorbainbridge.com/professorbainbridgecom/2009/11/theconstitutionality-of-the-delaware-takeover-statute.html; Ribstein, supra note 7, at 791. For present purposes, we note only that the doctrinal arguments presented in support of this approach are in some tension with the text and legislative history of the Williams Act and have not enjoyed widespread support among the courts.

${ }^{105}$ When Congress intends to limit the preemptive scope of its acts, it typically does so with standard language that explicitly protects state law from preemption rather than language preserving the jurisdiction of state administrative agencies. For a recent example, see, e.g., Consumer Product Safety Improvement Act of 2008, H.R. 4040, 110th Cong. §231 (2008) ( "Nothing in this Act . . shall be 


\section{Toward a Constitutional Review of the Poison Pill}

The provision's language and legislative history suggest that it was intended simply to preserve state securities agencies' jurisdiction, not limit the preemptive scope of federal securities law. ${ }^{106}$ Moreover, even when Congress does employ standard language expressing an intent to avoid preemption, the courts have increasingly concluded that ordinary preemption analysis-including an assessment of whether state law is an obstacle to Congress's objectives - should still apply. ${ }^{107}$ Thus, we do not expect courts to conclude that this provision forecloses analysis of whether state-law poison-pill rules frustrate Congress's objectives with respect to the Williams Act.

The courts are also unlikely to be persuaded to adopt a narrow view of the Williams Act's preemptive scope by arguments that courts typically presume that state law is not preempted by federal law, particularly in areas - such as substantive corporate law-where the states have traditionally had significant authority. For one thing, it is far from clear that the presumption against preemption, which has been the subject of considerable criticism from several commentators, remains a valid principle of constitutional law; ${ }^{108}$ indeed, the Supreme Court has expressly

construed to preempt or otherwise affect any warning requirement relating to consumer products or substances that is established pursuant to State law.”).

${ }^{106}$ Adolph Johnson, the Chief Counsel of the Public Service Commissioner of Wisconsin, suggested that this language be added to the Exchange Act in order to ensure only that each state was "left with authority to regulate in accordance with its laws and practices of persons engaged in strictly intrastate business within its borders," not to limit the preemptive scope of the Williams Act. Stock Exchange Regulation: Hearings on H.R. 7852 and H.R. 8720 before the Comm. On Interstate and Foreign Commerce, 73 Cong. Rec. 669 (1934).

107 See, e.g., Geier v. Am. Honda Motor Co., 529 U.S. 861, 869 (2000) (concluding that an explicit federal antipreemption provision did not limit the operation of ordinary preemption principles).

${ }^{108}$ The traditional formulation of the presumption is that the courts should "start with the assumption that the historic police powers of the States were not to be superseded by [a] Federal Act unless that was the clear and manifest purpose of Congress.” Rice v. Santa Fe Elevator Corp., 331 U.S. 218, 230 (1947). If it continues to apply at all, the presumption is limited to "field[s] in which the states have traditionally occupied.” Medtronic, Inc. v. Lohr, 518 U.S. 470, 485 (1996). 


\section{Toward a Constitutional Review of the Poison Pill}

declined to apply the presumption in several recent cases. ${ }^{109}$ Moreover, while the States have traditionally had significant authority in the area of corporate law, the Supreme Court has limited this presumption to areas that involve the States' police powers, which are not implicated by state regulation of corporate law. ${ }^{110}$ Finally, although the Court has twice addressed the preemptive scope of the Williams Act, none of the nine opinions issued in those cases even mentioned this presumption. ${ }^{111}$

Commentators have variously criticized the presumption for being unfaithful to the text of the Supremacy Clause, for inviting the courts to disregard congressional intent to preempt state law, and for being applied inconsistently. See Caleb Nelson, Preemption, 86 VA. L. REV. 225, 293 (2000) (arguing that the Supremacy Clause itself "rejects a general presumption that federal law does not contradict state law”); Viet D. Dinh, Reassessing the Law of Preemption, 88 GEO. L.J. 2085, 2092 (2000) (the presumption "disrupts the constitutional division of power between federal and state governments, rewrites the laws of Congress, or both”). See also CHRISTOPHER R. DRAHOZAL, THE SUPREMACY Clause: A Reference Guide to the United STATES Constitution 115 (2004) (collecting criticisms). "In short, it seems that no one is happy with the presumption except perhaps the Supreme Court itself." Id.

${ }^{109}$ See, e.g., Geier, 529 U.S. at 874 (refusing to apply a "special burden” to those attempting to show that federal law preempts state law); Buckman Cty. v. Plaintiffs' Legal Comm., 531 U.S. 341, 347-348 (2001) (holding, “in contrast to situations implicating federalism concerns and the historic primacy of state regulation of matters of health and safety[,] no presumption against preemption [more generally] applies”). The Court did apply the preemption in a more recent case, see Wyeth v. Levine, 129 S. Ct. 1187 (2008), but four Justices vigorously dissented from its application, see id. at 1228 (Alito, J., dissenting) (noting that the Court has "specifically rejected the argument . . . that the "presumption against preemption' is relevant” in cases involving preemption on the theory that state law frustrates the purposes and objectives of federal law).

${ }^{110}$ DRAHOZAL, supra note 97, at 113 ("The Court has not adopted a test for identifying areas traditionally regulated by the states, but it has linked the requirement to the state police power.").

111 CTS Corp. v. Dynamics Corp. of Am., 481 U.S. 69 (1985) (opinions of Justices Powell, Scalia, and White); Edgar v. MITE Corp., 457 U.S. 624 (1982) 


\section{Toward a Constitutional Review of the Poison Pill}

It is also unlikely that the courts will be persuaded to limit the preemptive reach of the Williams Act by Judge Easterbrook's view that the Act merely prescribes federal procedures for tender offers and that any state law that does not directly conflict with those procedures should not be held preempted. Under this framework, virtually no state lawincluding, for example, a punitive tax on tender offers-would be preempted by the Williams Act. While this view is certainly consistent with Justice Scalia's opinion in CTS, as we have noted, no other Justice joined that opinion.

Moreover, this approach is inconsistent with the extensive analysis of congressional intent joined by all eight of the other Justices in both MITE and CTS. ${ }^{112}$ None of that analysis - and similar analysis conducted by nearly every federal court to consider the preemptive scope of the Williams Act - would be necessary if this view were the law. And while several Justices, and particularly Justice Thomas, have often urged that the Court should not attempt to assess congressional purpose in preemption cases, a majority of the Court has consistently rejected that argument. ${ }^{113}$

For present purposes, the merits of a narrow approach to federal preemption doctrine in general, and to Williams Act preemption in particular, are not important. What is important is that this approach has not carried the day among jurists considering preemption challenges to state law based on the Williams Act. Thus, we think that the courts are unlikely to adopt this approach should they systematically consider such a challenge to state-law poison-pill rules. Although those rules would survive a constitutional challenge if the courts do adopt this framework,

(opinions of Justices White, Powell, O’Connor, Marshall, Brennan, and Rehnquist).

${ }^{112}$ See CTS, 481 U.S. at 82-83; MITE, 457 U.S. at 631-34.

113 See, e.g., Wyeth, 555 U.S. at 588 (Thomas, J., concurring in judgment) ("Preemption analysis should not be a free-wheeling judicial inquiry into whether a state statute is in tension with federal objectives"); see also Arizona v. United States, 132 S. Ct. 2492, 2521 (2012) (Thomas, J., dissenting) ("I have explained that the 'purposes and objectives' theory of implied preemption is inconsistent with the Constitution because it invites courts to engage in freewheeling speculation about congressional purpose that roams well beyond statutory text.”). 


\section{Toward a Constitutional Review of the Poison Pill}

the constitutionality of state-law poison-pill rules is much less certain under the alternative approaches the courts have used to address these challenges.

\section{Changing State Law to Avoid Preemption}

Thus far we have taken current state-law poison-pill rules as given, and have shown that they would likely be invalidated in the event that they were challenged on preemption grounds. State-law rules, however, may evolve — and, indeed, have evolved—considerably over time. Following the invalidation of some state-law poison-pill rules, or if state lawmakers recognize the risk that these rules will be invalidated, they may consider altering state corporate law to avoid preemption. In this Part, we describe changes to state law that would make reviewing courts less likely to conclude that the Williams Act preempts state-law poison-pill rules.

Before proceeding, we note that a comprehensive analysis of the alternative approaches that lawmakers might consider to state-law poisonpill rules is beyond the scope of this Article. In light of the significant risk that the courts might hold current state-law poison-pill rules preempted by the Williams Act, however, lawmakers may seek to alter state corporate law to avoid preemption. Thus, in this section we provide a preliminary assessment of how lawmakers might shield state corporate law from the Williams Act.

Although courts have taken a wide variety of approaches when interpreting the preemptive scope of the Williams Act, most judges considering constitutional challenges to state antitakeover statutes have focused on the length of time during which state law enables incumbents to block a tender offer from reaching shareholders. For example, in MITE the Supreme Court concluded that the Illinois statute challenged there was preempted in part because of the "extended delay" that the law might impose on the tender-offer process. ${ }^{114}$ And the Court upheld the Indiana

${ }^{114}$ MITE, 457 U.S. at 640; see also id. ("In enacting the Williams Act, Congress itself recognized that delay can seriously impede a tender offer, and sought to 


\section{Toward a Constitutional Review of the Poison Pill}

statute challenged in CTS in part because the Justices were convinced that the potential fifty-day delay imposed by that law was "reasonable." 115

Similarly, lower courts considering preemption challenges to state antitakeover statutes have emphasized the period of time that state law allows incumbents to delay a tender offer. For example, those courts that have required state laws to provide bidders with a meaningful opportunity for success have suggested that, to preserve a meaningful opportunity for hostile bidders, state law must not impose such a lengthy delay on tender offers that bidders would be deterred from proceeding. ${ }^{116}$ And the courts that have held that state laws must preserve some shareholder autonomy with respect to tender offers have indicated that state laws that impose lengthy delays compromise shareholders' freedom to decide whether to accept an offer. ${ }^{117}$

Moreover, we think that courts focusing on whether state takeover law enhances or reduces shareholder value would be more likely to uphold laws that do not empower directors to impose lengthy delays on the tender offer process. The principal costs that state-law poison-pill rules impose upon investors are the agency costs that arise when incumbents use these rules to perpetuate themselves in office despite the presence of a hostile bidder. $^{118}$ It follows, then, that laws that permit incumbents to block hostile bids for lengthy periods of time will expose investors to more

avoid it.” (quoting Great Western United Corp. v. Kidwell, 577 F.2d 1256, 1277 (5th Cir. 1978) (internal quotation marks omitted)) .

${ }^{115}$ CTS, 481 U.S. at 82-83; see also id. (noting that, by contrast, the Illinois statute struck down in MITE had the "potential [to impose] infinite delay" on the tender-offer process).

${ }^{116}$ See, e.g., BNS v. Koppers, 683 F. Supp. 458, 469 (D. Del. 1988) (whether a bidder has been given a meaningful opportunity for success depends, among other things, on whether the state law "impose[s] an indefinite or unreasonable delay on offers").

117 See, e.g., Hyde Park Partners, L.P. v. Connolly, 839 F.2d 837, 853 (1st Cir. 1988).

${ }^{118}$ See, e.g., Bebchuk et al., supra note 54, at 919 (describing the standard agency costs that accompany the use of poison pills). 


\section{Toward a Constitutional Review of the Poison Pill}

significant agency costs, and thus be less likely to enhance shareholder value.

Taken together, in our view the cases interpreting the preemptive scope of the Williams Act suggest that state-law poison-pill rules that limit the period of time during which directors can use the pill to block a tender offer they disfavor will be more likely to survive constitutional scrutiny. Thus, lawmakers seeking to shield these rules from preemption should consider placing meaningful limitations on how long directors may keep poison pills in place. For example, state law could stipulate that a pill may be kept in place for only a specified period of time without shareholder approval.

Although the precise scope of such time limits is beyond the scope of this Article, we note that corporate law in several non-U.S. jurisdictions limits the amount of time during which boards may use a poison pill to block a tender offer from shareholder consideration. For example, Canadian law provides that a poison pill may not be kept in place without shareholder approval if regulators conclude that the pill has given directors sufficient time to consider alternatives to the hostile offer. ${ }^{119}$ Similarly, Japanese law allows companies to adopt poison pills only if there is some mechanism for shareholders to eliminate them, including a sunset provision limiting the time during which the pill may be kept in place without shareholder approval. ${ }^{120}$ Thus, as experience in other jurisdictions has shown, legal arrangements limiting the time during which directors may use a poison pill to block a tender offer from being considered by shareholders can be successfully implemented.

119 See, e.g., In re Canadian Jorex Limited \& Manville Oil \& Gas Ltd., 16 O.S.C.B. 257, 267 (1992).

120 See, e.g., Guhan Subramanian, The Emerging Problem of Embedded Defenses: Lessons from Air Pilots Ass'n, Int'l v. UAL Corp., 120 HARV. L. REV. 1239, 1243 (2007) (citing MinISTRY OF ECON., TRADE \& INDUS. \& MINISTRY OF JustiCE, GUIDELINES REGARDING TAKEOVER DEFENSES FOR THE PURPOSES OF PROTECTION AND ENHANCEMENT OF CORPORATE VALUE AND SHAREHOLDERS' COMMON INTERESTS 9 (2005)). 


\section{Toward a Constitutional Review of the Poison Pill}

Indeed, even in the United States many once believed that state law would develop, over time, to require that poison pills include a mechanism enabling shareholders to redeem poison pills after a limited period of time. Anticipating that the law might move in that direction, in 1987 the creators of the original poison pill designed a second-generation pill that allowed "qualified" bidders to call a special shareholder meeting within 90 to 120 days following the bidder's request—and providing that shareholders could, by majority vote at the special meeting, redeem the pill. ${ }^{121}$

Of course, since 1987 state law has taken a different path, leading practitioners to drop the special meeting procedure from subsequent versions of the pill. State law today authorizes incumbents to use the pill to delay hostile offers for lengthy periods of time without shareholder approval. As we have explained, however, this shift brings state-law poison-pill rules into significant tension with the Williams Act. Lawmakers seeking to address that tension would do well to recall that the creators of the pill itself initially contemplated limits on the amount of time that incumbents could use the pill to block a tender offer. By changing state-law poison-pill rules to authorize the use of pills only for a limited period of time, lawmakers could render the rules more likely to be held consistent with the William Act.

\section{CONCLUSION}

In this Article, we have challenged the widely shared view that the significant line of cases in which federal courts reviewed the constitutionality of state antitakeover laws is no longer practically relevant. We have shown that, by contrast, the principles developed in these cases raise serious questions about the validity of the state-law rules authorizing the use of the poison pill, the antitakeover device that plays a

121 See Wachtell, Lipton, Rosen \& Katz, client memorandum, A Second Generation Share Purchase Rights Plan (July 14, 1987) (describing this mechanism). See also Martin Lipton, Corporate Governance in the Age of Finance Corporatism, 136 U. PA. L. REV. 1, 70 (1987) (“[T]he new pill provides that, under certain circumstances, a special shareholders meeting will be held to determine whether the pill should be redeemed.”). 


\section{Toward a Constitutional Review of the Poison Pill}

key role in the corporate landscape. We have conducted a systematic analysis of the constitutional validity of these rules and have provided a framework for assessing constitutional challenges to them.

Our analysis indicates that challenges to the validity of state-law poison-pill rules would likely have major consequences. We have shown that such challenges could well result in the invalidation of the current state-law rules governing poison pills on grounds of Williams Act preemption. Furthermore, while state lawmakers could change these rules to enable them to survive a preemption challenge, the changes necessary to accomplish this-imposing significant limits on the length of time during which incumbents may use a poison pill to block an unsolicited offer-would themselves bring about major changes to how American corporations are governed and acquired.

Either way, recognizing the tension between current state-law poison-pill rules and the Williams Act can have profound implications for the corporate-law landscape. We hope that our analysis will contribute to the recognition of this critical tension, and that the framework we have provided will prove useful to scholars, lawmakers, and courts in their future examination of this important subject. 